\title{
CNG-Modulin: A Novel Ca-Dependent Modulator of Ligand Sensitivity in Cone Photoreceptor cGMP-Gated Ion Channels
}

\author{
Tatiana I. Rebrik, ${ }^{1,2}$ Inna Botchkina, ${ }^{1}$ Vadim Y. Arshavsky, ${ }^{2}$ Cheryl M. Craft, ${ }^{3}$ and Juan I. Korenbrot ${ }^{1}$ \\ ${ }^{1}$ Department of Physiology, School of Medicine, University of California at San Francisco, San Francisco, California 94143, ${ }^{2}$ Albert Eye Research Institute, \\ Duke University Medical Center, Durham, North Carolina 27710, and ${ }^{3}$ Mary D. Allen Laboratory for Vision Research, Doheny Eye Institute, Departments of \\ Ophthalmology and Cell and Neurobiology, Keck School of Medicine of the University of Southern California, Los Angeles, California 90033-9224
}

The transduction current in several different types of sensory neurons arises from the activity of cyclic nucleotide-gated (CNG) ion channels. The channels in these sensory neurons vary in structure and function, yet each one demonstrates calcium-dependent modulation of ligand sensitivity mediated by the interaction of the channel with a soluble modulator protein. In cone photoreceptors, the molecular identity of the modulator protein was previously unknown. We report the discovery and characterization of CNG-modulin, a novel 301 aa protein that interacts with the $\mathrm{N}$ terminus of the $\beta$ subunit of the cGMP-gated channel and modulates the cGMP sensitivity of the channels in cone photoreceptors of striped bass (Morone saxatilis). Immunohistochemistry and single-cell PCR demonstrate that CNG-modulin is expressed in cone but not rod photoreceptors. Adding purified recombinant CNG-modulin to cone membrane patches containing the native CNG channels shifts the midpoint of cGMP dependence from $\sim 91 \mu \mathrm{M}$ in the absence of $\mathrm{Ca}^{2+}$ to $\sim 332 \mu \mathrm{M}$ in the presence of $20 \mu \mathrm{M} \mathrm{Ca}^{2+}$. At a fixed cGMP concentration, the midpoint of the $\mathrm{Ca}^{2+}$ dependence is $\sim 857 \mathrm{nM}^{2+}{ }^{2+}$. These restored physiological features are statistically indistinguishable from the effects of the endogenous modulator. $\mathrm{CNG}^{-m o d u l i n}$ binds $\mathrm{Ca}^{2+}$ with a concentration dependence that matches the calcium dependence of channel modulation. We conclude that CNG-modulin is the authentic $\mathrm{Ca}^{2+}$-dependent modulator of cone CNG channel ligand sensitivity. CNG-modulin is expressed in other tissues, such as brain, olfactory epithelium, and the inner ear, and may modulate the function of ion channels in those tissues as well.

\section{Introduction}

Sensory neurons such as retinal rod and cone photoreceptors and ciliated olfactory sensory neurons (OSNs) respond to their adequate stimuli with changes in membrane current mediated by the activity of cyclic nucleotide-gated (CNG) channels. The channels' structure and function differ among various sensory neurons (Kaupp and Seifert, 2002; Biel and Michalakis, 2009). Functional differences include CNG channels' sensitivity to specific cyclic nucleotides and their relative $\mathrm{Ca}^{2+}$ permeability. Yet, in all sensory neurons, the channels exhibit Ca-dependent modulation of ligand sensitivity critical for cell function, although the extent and $\mathrm{Ca}$ dependence of the modulation varies among the cells (Bradley et al., 2005).

Ca dependence of ligand sensitivity is not an intrinsic property of CNG channels; it arises from the interaction between the channel and a modulator protein. Modulation is observed in intact cells but not in detached membrane fragments. Moreover, when

Received Nov. 1, 2011; revised Dec. 28, 2011; accepted Jan. 10, 2012.

Author contributions: T.I.R., V.Y.A., C.M.C., and J.I.K. designed research; T.I.R., I.B., and J.I.K. performed research; T.I.R. contributed unpublished reagents/analytic tools; T.I.R. and J.I.K. analyzed data; T.I.R. and J.I.K. wrote the paper.

This work was supported in part by NIH Grants EY020654, EY014974, EY005498, EY015851, EY03040, EY10336, and EY5722. We thank Dr. Xuemei Zhu for technical expertise in the original yeast two-hybrid screen design and Dr. Freddi I. Zuniga for technical support.

Correspondence and requests for materials should be addressed to Tatiana Rebrik, Albert Eye Research Institute, Duke University Medical Center, Durham, NC 27710. E-mail: tatiana.rebrik@duke.edu.

DOI:10.1523/JNEUROSCI.5518-11.2012

Copyright $\odot 2012$ the authors $\quad 0270-6474 / 12 / 323142-12 \$ 15.00 / 0$ cells are made leaky, the extent of channel modulation progressively diminishes with time, suggesting that the modulator is soluble and can be lost by diffusion. In both OSNs and rods, the modulator is calmodulin. In OSNs, modulation is lost over time from "macro" patches detached from cilia (Kramer and Siegelbaum, 1992) and added calmodulin fully restores it (Frings et al., 1992; Chen and Yau, 1994; Lynch and Lindemann, 1994; Reuter and Frings, 2001; Trudeau and Zagotta, 2003). In rods, modulation is lost over time from truncated outer segments (Nakatani et al., 1995; Sagoo and Lagnado, 1996), and added calmodulin restores modulation in rod membrane patches (Gordon et al., 1995) and membrane vesicles containing the CNG channels (Hsu and Molday, 1993; Bauer, 1996).

In cones, $\mathrm{CNG}$ channel modulation is significant and occurs over the physiological range of cytoplasmic $\mathrm{Ca}^{2+}$ concentration (Rebrik and Korenbrot, 1998; Rebrik et al., 2000). The speed, photosensitivity, stability, and adaptation of the transduction signal depend on CNG channel modulation (Korenbrot, 2012). Just as in rods and OSNs, cone channel modulator was predicted to be a soluble protein because modulation is absent in cone membrane patches (Hackos and Korenbrot, 1997) and is lost over time from electropermeabilized cells and from cones studied with whole-cell patch electrodes (Rebrik and Korenbrot, 1998, 2004). However, the molecular identity of the cone channel modulator was unknown. Unlike in rods and OSNs, calmodulin is not the cone CNG channel modulator. Adding calmodulin to cone membrane patches (Hackos and Korenbrot, 1997; Haynes and Stotz, 1997) or patches from oocytes expressing cone channels 
(Peng et al., 2003) does not restore modulation to the extent measured in intact cells.

We report here the molecular identification and functional characterization of a novel protein, CNG-modulin, which acts as the modulator of $\mathrm{Ca}$-dependent ligand sensitivity of CNG channels in cones. CNG-modulin binds the amino terminus of the cone $\mathrm{CNG}$ channel $\beta$ subunit. It is expressed in cone, but not rod photoreceptors. Adding CNG-modulin to cone membrane patches results in modulation of the CNG channels ligand sensitivity to an extent and with $\mathrm{Ca}^{2+}$ dependence indistinguishable from those measured in intact photoreceptors. Furthermore, CNG-modulin binds $\mathrm{Ca}^{2+}$ with affinity that matches the $\mathrm{Ca}^{2+}$ dependence of channel modulation.

\section{Materials and Methods}

Vertebrate animals. Research was conducted on striped bass (Morone saxatilis) without regard to sex. Animal upkeep and experimental protocols were approved by the Institutional Animal Care and Use Committees at both the University of California, San Francisco (UCSF) and Duke University and met all requirements of the NIH Office of Laboratory Animal Welfare and the Association for Assessment and Accreditation of Laboratory Animal Care International.

Yeast two-hybrid screen. We screened a striped bass retina cDNA library using a commercial kit following the manufacturer's guidelines (Matchmaker Two-Hybrid System 3; Clontech). From the sequence of striped bass CNG channel $\beta$ subunit (GenBank accession no. DQ172909) (Paillart et al., 2006) two bait plasmids were constructed in the pGBKT7 vector: (1) CNGB3N consists of base pairs 1-828, which encode the entire N-terminal cytoplasmic domain, and (2) CNGB3C consists of base pairs 1501-2265, which encode the entire C-terminal cytoplasmic domain. Positive clones were identified at high stringency by the simultaneous expression of three reporter genes: ADE2, HIS3, and LacZ. Potential positives were verified by two rounds of cotransformations.

Cell transfection and microscopic observations. tsA201 cells (a cell line transformed from HEK 293 cells to constitutively express T-antigen) were cultured in DMEM H21 media using standard procedures. Cells were transfected with expression vectors either one at a time or in pairs, but always at the same concentration $\left(0.4 \mu \mathrm{g}\right.$ DNA/ $9 \mathrm{~mm}^{2}$ over $80-90 \%$ confluent cultures) using Lipofectamine 2000 (Invitrogen). Thirty-six hours later, cells expressing the HaloTag protein were incubated in HaloTag-tetramethylrhodamine (TMR) ligand (2.5 $\mu \mathrm{M}$ for $15 \mathrm{~min}$ at $37^{\circ} \mathrm{C}$ followed by $30 \mathrm{~min}$ without the ligand). Regardless of the transfecting vector, after $36 \mathrm{~h}$ cells were washed free of medium in the culture wells, lifted off the plastic surface using $0.1 \%$ trypsin in $\mathrm{Ca}^{2+} / \mathrm{Mg}^{2+}$-free PBS, washed by centrifugation in a salt solution [containing the following (in mM): $140 \mathrm{NaCl}, 2.5 \mathrm{KCl}, 5 \mathrm{NaHCO}_{3}, 1 \mathrm{Na}_{2} \mathrm{HPO}_{4}, 1 \mathrm{MgCl}_{2}, 1$ $\mathrm{CaCl}_{2}, 10$ glucose, and 10 HEPES, $\mathrm{pH} 7.5$ ], and finally resuspended at a density of $\sim 5 \times 10^{5}$ cells $/ \mathrm{ml}$. The suspension was kept on ice for up to $3 \mathrm{~h}$. Before microscopic observation, $200 \mu \mathrm{l}$ of the cell suspension was placed on a poly-L-lysine-coated $(0.1 \mathrm{mg} / \mathrm{ml})$ glass coverslip that formed the bottom of a perfusion chamber. After $10 \mathrm{~min}$ at room temperature, the chamber was placed on the stage of the microscope and vigorously perfused to wash away unattached cells. The chamber was intermittently perfused in the course of total internal reflectance fluorescent (TIRF)/ Förster resonance energy transfer (FRET) measurements over the following $30 \mathrm{~min}$.

Single-cell reverse transcription-PCR. Single-cell reverse transcription (RT)-PCR was performed using single or twin cones isolated from the bass retina, as detailed previously (Paillart et al., 2006). Individual photoreceptors were isolated by gentle mechanical stretching of a retina and transferred in suspension into a chamber held on a microscope stage. Cells attached to concanavalin A-coated glass coverslip that formed the chamber's bottom. The cell-bathing Ringer's solution in the chamber was exhaustively exchanged before collecting individual cells with a microscopic suction pipette in a minimal volume. The micropipette contents were expelled into $10 \mu \mathrm{l}$ of hypotonic lysis buffer containing $10 \mathrm{~mm}$ Tris-Cl, pH 8.0, 0.68 mm DTT, and 0.5 U RNAseOut (Invitrogen) and immediately subjected to the RT reaction using Sensiscript Reverse Transcriptase (Qiagen) in $20 \mu \mathrm{l}$ reaction for $1 \mathrm{~h}$ at $37^{\circ} \mathrm{C}$. The reaction was terminated by incubating it for $5 \mathrm{~min}$ at $93^{\circ} \mathrm{C}$ and then cooling it to $4^{\circ} \mathrm{C}$. The solution was used immediately or stored at $-20^{\circ} \mathrm{C}$. Two rounds of 30 cycles PCR amplification were performed using HotStart TaqDNA polymerase (Qiagen). Four microliters of the RT reaction mixture were used in a final volume of $25 \mu \mathrm{l}$ in the first round of PCR amplification; $1 \mu \mathrm{l}$ of the first round product was used as a template for the second amplification. Two sets of primers were used to assess the expression of CNG-modulin: (1) a forward primer ( $5^{\prime}$ AGCTCCACAGCCAGGAACTA-3') and reverse primer (5'-AGACCCAGTCTTTCTTGCGA-3') with amplicon size $246 \mathrm{bp}$, and (2) a forward primer ( $5^{\prime}$-AGTCCAAGGAGGCTGCAGTA-3') and reverse primer (5'-ACTGGCTTGGTGATTTGAGG-3') with amplicon size $300 \mathrm{bp}$. PCR products were gel purified and sequenced.

Tissue RT-PCR. Isolated retina, olfactory rosette, inner ear, heart, skeletal muscle, brain, spinal cord, gonad, intestine, spleen, kidney, and gill tissue were freshly dissected. Twenty-five milligrams of each tissue were frozen immediately and stored under liquid nitrogen. Frozen tissue was triturated under liquid nitrogen and total RNA isolated using RNAqueous kit (Ambion) according to the manufacturer's instructions. One microgram of total RNA from each tissue was used in a $20 \mu \mathrm{l}$ reaction to synthesize first-strand cDNA using SuperScript III Reverse Transcriptase (Invitrogen) primed with oligo-dT. Six milliliters of the RT reaction product were used for PCR amplification of CNG-modulin with the same primers and protocol as were used in the single-cell PCR. The expression of striped bass $\beta$-actin mRNA (GenBank accession no. L36342) was assessed in each tissue sample using forward primer $5^{\prime}$ CAGGGAGAAGATGACCCAGA-3' and reverse primer 5' -TGCTGTTGTAGGTGGTCTCG-3'; the reaction product size was $500 \mathrm{bp}$.

Antibodies and immunohistochemistry. Polyclonal antibody against CNG-modulin was produced in rabbits immunized with the synthetic peptide CQMQEDEIQLLK corresponding to CNG-modulin fragment amino acids $77-87$ conjugated to KLH. This antibody was affinity purified from serum on the same antigenic peptide using Sulfolink Plus columns (Pierce Biotechnology). Antibody specificity was affirmed by Western blotting of retinal lysate (see Results) (see Fig. $4 B$ ), as recommended in a Toolbox paper in this journal (Rhodes and Trimmer, 2006). The antibody against rod transducin $\alpha$ subunit $\left(\mathrm{G}_{\alpha \mathrm{t} 1}\right)$ is commercially available (SC-389; Santa Cruz Biotechnology).

Frozen sections for immunohistochemistry were cut from striped bass eye cups that had been dissected and fixed overnight at $4^{\circ} \mathrm{C}$ in $4 \%$ paraformaldehyde in $0.1 \mathrm{~m}$ PBS buffer. Fixed tissue was infiltrated with OCT through a slow sequence of exchanges in OCT/sucrose mixtures (Barthel and Raymond, 1990). Equatorial sections $(8-10 \mu \mathrm{m}$ thick) were cut along the anterior-to-posterior axis and transferred onto Superfrost Plus slides, dried, and then incubated first for $1 \mathrm{~h}$ in $5 \%$ goat serum and $0.2 \%$ Triton X-100 in PBS buffer followed by overnight incubation at $4^{\circ} \mathrm{C}$ with anti-CNG-modulin antibody in PBS buffer containing $0.1 \%$ Triton X-100. Slides were then washed three times with PBS and incubated for $1 \mathrm{~h}$ at room temperature with goat anti-rabbit antibody labeled with Alexa Fluor 594 in PBS. Cell nuclei were counterstained with Hoechst 33342. Slides were rinsed three times in PBS and and coverslipped with Fluoromount G (Electron Microscopy Sciences).

TIRF/FRET studies. TIRF microscopy was conducted at the Nikon Imaging Center at UCSF using a Nikon Apo TIRF $100 \times(1.49$ NA) objective in a Nikon TE2000E inverted microscope equipped with a perfect focus attachment. Lasers produced $488 \mathrm{~nm}$ and $561 \mathrm{~nm}$ fluorescence excitation lines, and appropriate epicubes and fluorescence emission filters allowed fluorescence emission measurements in the FITC or TMR spectral regions. Digital images were acquired with a cooled CCD camera (Cascade II EMCCD; Photometrics) and NIS-Elements software (Nikon).

Images were analyzed with SimplePCI imaging software (Hamamatsu). To quantify fluorescence emission intensity, the perimeter of the focused cell image was traced by hand with a cursor. The 12-bit mean gray level of the area encompassed by the traced image was determined. The identical area tracing was also placed over the cell-free background immediately adjacent to the cell, and the background mean gray level was determined. Net gray level was computed by subtracting background from cell's gray level. The 
net gray levels for each cell in the EGFP and TMR channels were determined with the identical tracing before and after bleaching the fluorescent donor.

Production and purification of recombinant CNG-modulin. Recombinant CNG-modulin was produced in Escherichia coli using small ubiquitin-like modifier (SUMO) fusion technology (Panavas et al., 2009) and purified by a commercial service (GenScript). CNG-modulin cDNA was subcloned into pSUMO vector using StuI. The construct was verified by DNA sequencing and used to transfect E. coli [strain BL21(DE3)]. Bacteria were cultured at $37^{\circ} \mathrm{C}$ for $4 \mathrm{~h}$ (OD of cell suspension measured at $600 \mathrm{nM}, \sim 0.8)$ and then induced by $1 \mathrm{~mm}$ isopropyl- $\beta$-D-thiogalactoside at $37^{\circ} \mathrm{C}$ for $4 \mathrm{~h}$. Cells were harvested by centrifugation and lysed by sonication. The lysate was then centrifuged at 11,000 rpm for 10 min and the precipitant collected. The precipitant was washed twice with wash buffer (20 mM Tris buffer, $\mathrm{pH} 8.0$, containing $0.15 \mathrm{M} \mathrm{NaCl}, 1 \%$ Triton X-100, and $10 \mathrm{~mm}$ EDTA), then twice with the same buffer now containing $1.5 \mathrm{M}$ urea. The inclusion bodies were resolved with $4 \mathrm{~m}$ urea and centrifuged. The supernatant was loaded onto an Ni-iminodiacetic acid (IDA) column and washed with a washing buffer (Tris- $\mathrm{HCl}, 4 \mathrm{M}$ urea, $\mathrm{pH}$ 8) containing $20 \mathrm{~mm}$ imidazole, and then the fusion protein was eluted with $250 \mathrm{~mm}$ imidazole in the washing buffer. The protein was refolded by diluting (1:10) with PBS containing $0.4 \mathrm{M} \mathrm{L}$-arginine, $1 \mathrm{~mm}$ reduced glutathione, $1 \mathrm{~mm}$ oxidized glutathione, and $10 \%$ glycerol. The mixture was kept at $4^{\circ} \mathrm{C}$ for $24 \mathrm{~h}$ and then centrifuged, and the supernatant collected. It was then dialyzed against PBS containing $10 \%$ glycerol and then digested with $400 \mathrm{U}$ of SUMO protease. Tag-free CNGmodulin was recovered by batching with the Ni-IDA column, which was pre-equilibrated with PBS containing $10 \%$ glycerol (see Fig. $1 A$, lane 1) The recovered CNG-modulin was batched for the second time with the Ni-IDA column for further purification (see Fig. 1 A, lane 2). Purity of the recovered protein was $85 \%$, as determined using BandScan software. Purified protein wasstored at $-20^{\circ} \mathrm{C}$ in $10 \%$ glycerol-PBS. The estimated CNG-modulin molecular weight is $32.7 \mathrm{kDa}$, calculated from its amino acid composition. Apparent molecular mass estimated from SDS-PAGE and indicated in various figure legends ranges between 31 and $34 \mathrm{kDa}$. This variability reflects the well-known influence on the apparent mass of the chemicals used to buffer $\mathrm{pH}$, the ionic composition of the running buffer, and the percentage of acrylamide in the gel. Experimental conditions differed in each of the gels.

Electrophysiological measurements in detached membrane patches. Methods to record currents in bass cone outer-segment membrane patches have been detailed previously (Picones and Korenbrot, 1992; Hackos and Korenbrot, 1999). Single cones were dissociated from isolated, dark-adapted retinas by gentle enzymatic dissociation. A suspension of the isolated photoreceptors was deposited on a concanavalin A-coated glass coverslip that formed the bottom of a recoding chamber. The recording chamber consisted of two continuous compartments that could be separated by a movable barrier. Cells were held in one compartment and perfused intermittently with a fish Ringer's solution. Tight seal electrodes were applied onto the side of the outer segment. After forming a gigaseal and detaching the electrode to obtain an inside-out membrane patch, the electrode was moved under the solution surface to the second compartment and placed within $100 \mu \mathrm{m}$ from the output of a microperfusion system. The barrier was then moved to isolate the two compartments from each other. Solutions bathing the membrane cytoplasmic surface were rapidly exchanged using an 8 or 16 channel micromanifold operated under pressure and controlled through the use of electronic valves (SVDS1 and PC-16 valve controller; Bioscience Tools).

Voltage-clamped membrane currents were recorded at room temperature using a patch clamp amplifier (Axopatch 1D; Molecular Devices). Membrane voltage was held at $0 \mathrm{mV}$ and current changes measured in response to $100 \mathrm{~ms}$ voltage steps to $-40 \mathrm{mV}$. Analog signals were low bandpassed below $1 \mathrm{kHz}$ with an eight-pole Bessel Filter (Frequency Devices) and acquired at a $5 \mathrm{kHz}$ digital sampling rate using a data acquisition system and software (Digidata 1322A and pClamp; Molecular Devices).

The extracellular surface of a detached membrane patch was bathed by the electrode filling solution composed of the following (in $\mathrm{mM}$ ): 157 $\mathrm{NaCl}, 10$ HEPES, 5 EGTA, and 5 EDTA, pH 7.5. The intracellular surface was bathed with a solution composed of the following (in mM): $157 \mathrm{NaCl}$ and 10 HEPES, $\mathrm{pH} 7.5$, and varying $\mathrm{Ca}^{2+}$ concentration, as controlled with HEDTA/Ca ${ }^{2+}$ buffer.

Solutions of defined $\mathrm{Ca}^{2+}$ concentrations. Accurate $\mathrm{Ca}^{2+}$ concentration were achieved by mixing appropriate volume ratios of two solutions, one containing HEDTA ( $10 \mathrm{~mm})$ free of any divalent cations and another with the same HEDTA concentration but titrated with added $\mathrm{CaCl}_{2}$ to yield every HEDTA molecule bound to a single $\mathrm{Ca}^{2+}$ ion without additional free $\mathrm{Ca}^{2+}$. The protocol of the solution preparation was detailed previously (Hackos and Korenbrot, 1997). Although CNG-modulin itself binds $\mathrm{Ca}^{2+}$, its concentration was very low (90 nM in patch-clamp experiments and $300 \mathrm{~nm}$ in tyrosine fluorescence measurements) compared with that of HEDTA $(10 \mathrm{~mm})$; therefore, we neglected it when calculating free $\mathrm{Ca}^{2+}$ concentration from the mole ratio of $\mathrm{Ca}^{2+}$-free to $\mathrm{Ca}^{2+}$-saturated HEDTA.

$\mathrm{Ca}^{2+}$ binding to CNG-modulin immobilized on PVDF membranes. Recombinant CNG-modulin, bovine heart Calmodulin, and proteins of biological origin as molecular weight standards (SeeBlue Plus2; Invitrogen) were separated by SDS-PAGE and electroblotted onto PVDF membranes. Following the protocols of (Tatsumi et al., 1997), the PVDF membranes were exhaustively washed free of electroblotting solution and then incubated in a solution containing the following (in $\mathrm{mM}$ ): 60 $\mathrm{KCl}, 5 \mathrm{MgCl}_{2}, 10$ imidazole buffer, $\mathrm{pH} 6.8$, and $1 \mathrm{CaCl}_{2}$ for $1 \mathrm{~h}$ at room temperature. They were then rinsed in $20 \%$ ethanol, washed repeatedly in deionized water (MilliQ System; Millipore), and then incubated with 1 mM Quin2 in water for $1 \mathrm{~h}$ at room temperature followed by exhaustive washing with deionized water. Digital images of the blots were acquired under UV illumination and analyzed using SimplePCI software (Hamamatsu).

Fluorescence spectroscopy. Fluorescence emission spectra were measured at $22^{\circ} \mathrm{C}$ in a spectrofluorimeter (RF-5301PC; Shimadzu). Fluorescence was excited at $280 \mathrm{~nm}$, and emission spectra measured in the range between 290 and $400 \mathrm{~nm}$. Emission spectra were corrected to remove Raman scattering by subtracting from each spectrum that of protein-free HEDTA-buffered solution.

\section{Results}

To identify candidate cone CNG ion channel modulators, we conducted a yeast two-hybrid screen of the striped bass retinal cDNA library. The library was prepared from retinal mRNA and consisted of $\sim 5.5 \times 10^{7}$ clones. CNG channels of olfactory sensory neurons (Liu et al., 1994; Varnum and Zagotta, 1997) and rods (Grunwald et al., 1998; Weitz et al., 1998) are modulated by calmodulin that binds the $\beta$ subunit cytoplasmic domains. We assumed the same would be true of the cone CNG modulator and screened the yeast library with two different baits: CNGB3N, which encodes the 276 aa N-terminal cytoplasmic domain, and CNGB3C, which encodes the 255 aa C-terminal cytoplasmic domain. The screen yielded 77 positive clones for the $\mathrm{N}$ terminus bait and none for the $\mathrm{C}$ terminus. A total of 12 clones with the identical cDNA encoding an open reading frame, which translated into a novel 301 aa, 32.7 $\mathrm{kDa}$ protein, were identified. Based on the functional characterization, we named the novel protein CNG-modulin (GenBank accession no. FJ711702) (Fig. 1B).

\section{CNG-modulin binds the $\mathrm{N}$-terminal cytoplasmic domain of bass CNGB3 in cultured vertebrate cells}

Recent technical improvements make discoveries of proteinprotein interaction in yeast library screens less likely to yield false positives than observed previously. Nonetheless, protein interactions in the yeast cytoplasmic milieu could be different than those in vertebrate cells. To address this concern, we retested interaction between CNG-modulin and CNGB3N in vertebrate cells (tsA201).

Cultured tsA201 cells were transfected with CNG-modulin and/or CNGB3N. We assessed the cellular localization of the two 
A

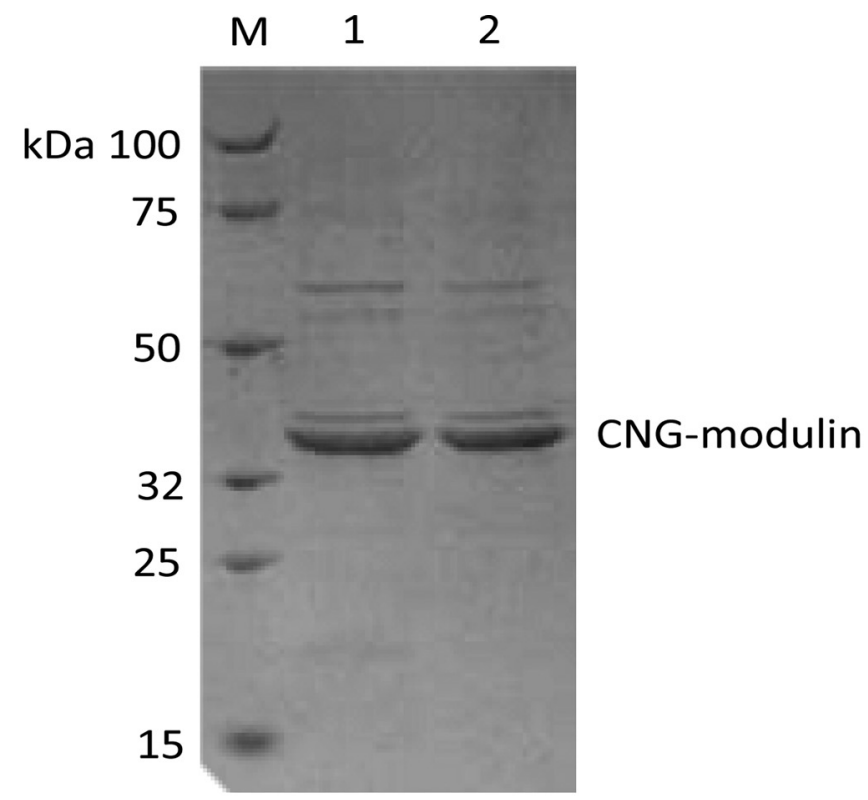

B

1 MAAGTLBGDSHMEELLDQGLGMEETDHGLLRRPSLKBSYHSDSLLAPDTD

51 FMTDDRSSAASGLDVADRLTYLEQRMQMQBDEIQLLKMALADVLKRLNIS

101 BEYQAAAAAGRRPSGAKARPVSLALPSRPPMVTSSTASLKKSTTLPSSST

151 ARNYSPTPPRSGVKSPLGSVKDSPCKTARSRPTSAASTCKKPQRGKSKBA

201 AVSVGTRRVTHCKVTMQIYLSPLARKTGSSBTAKSAAAVPANSRPMATPQ

251 AKGGNKLQARKTTPTFTLNLQKTTSSHNSAQDTSSYKSPLKSPSQYFQIC

301 Y*

Figure 1. A, Steps in the purification of recombinant CNG-modulin. Shown is an image of a gel after SDS-PAGE separation of proteins recovered at various stages of purification. Lane M, Molecular weight markers (GenScript MM0900). Lane 1, Proteins recovered after the first round of purification on an Ni-IDA column. Lane 2, Proteins recovered after the final round of purification on an Ni-IDA column. Apparent molecular mass of CNG modulin is $34 \mathrm{Kd}$. $\boldsymbol{B}$, Deduced amino acid sequence of CNG-modulin (GenBank accession FJ711702). The box highlights the peptide used to generate CNG-modulin-specific antibodies. and CNGB3 colocalized at the cell membrane and appeared as a ring at the cell perimeter, but the extent to which CNGmodulin was detectable in the cytoplasmic volume varied from cell to cell. Since the amount of CNG-modulin removed from the cytoplasmic pool by the membrane-bound CNGB3 is determined by the relative expression levels of the two proteins, then the cell-to-cell variance in the amount of CNG-modulin that remains in the cytoplasm reflects the fact that the expression level of each protein was variable and not under experimental control. The colocalization of CNGmodulin and CNGB3N at the plasma membrane of tsA201 cells confirms that the proteins do interact with each other in vertebrate cells, just as they do in yeast.

To assay the interaction between CNGmodulin and CNGB3N with a quantitative method, we measured FRET between the fluorophores in the two fusion proteins (Periasamy and Day, 2005). FRET between two fluorophores of appropriately overlapping emission and excitation spectra, such as EGFP and TMR, occurs only if they are, on average, $<100 \AA$ away from each other, typically around $60 \AA$ (Lakowicz, 1999). We measured FRET using total internal reflection fluorescence. This technique is applicable to cells attached to a thin glass coverslip and reveals cell structures limited to $\sim 100 \mathrm{~nm}$ from the coverslip surface, that is, principally the fluorescent molecules anchored at the cell membrane (Periasamy and Day, 2005).

We measured FRET efficiency between proteins either coexpressed or expressed individually. Proteins were fluorescently labeled by fusing them with fluorescent proteins: CNG-modulin with HaloTag and CNGB3N with EGFP-F. HaloTag was rendered fluorescent by binding the TMR ligand. The EGFP-F fusion protein also expresses a C-terminal farnesylation signal that targets it to the inner surface of the plasma membrane.

Cellular distribution patterns of the fluorescently tagged proteins are shown in Figure 2. TMR-labeled CNG-modulinHaloTag expressed alone was homogeneously distributed throughout the cell cytoplasm and excluded from the nuclei, identified by staining with Hoechst 33342 blue fluorescent dye (Fig. 2A). CNGB3N-EGFP-F expressed alone was localized at the inner surface of the plasma membrane, where it appeared as a bright fluorescent ring when imaged with a confocal fluorescence microscope (Fig. $2 \mathrm{~B}$ ). In a similar confocal fluorescent image, CNG-modulin expressed alone appears homogenously distributed in the cytoplasm but, again, excluded from the nucleus (Fig. $2 \mathrm{~B}$ ). In contrast, when the proteins were coexpressed, they colocalized at the cell membrane. Figure $2 C$ are confocal images of the same cell at the same optical plane, but captured under different color channels to reveal the localization of each protein. Overlay of the two images demonstrates that CNGB3N binds soluble CNG-modulin and confines it almost entirely to the plasma membrane. In every cell we examined, CNG-modulin
CNGB3N-EGFP-F and CNG-modulin-HaloTag-TMR using the acceptor photobleaching method (photobleaching-dependent fluorescence enhancement) (Centonze et al., 2003). We acquired TIRF images of cells expressing both fluorescent proteins before and after bleaching TMR (Fig. 3). Before bleaching TMR (acceptor), EGFP (donor) fluorescence is quenched by the nonradiative energy transfer from EGFP to TMR. After bleaching TMR, EGFP fluorescence is enhanced because it is no longer quenched, since the acceptor is removed. The efficiency of energy transfer between EGFP and TMR is quantified by measuring the emission intensity of EGFP fluorescence before and after bleaching TMR:

$$
E_{\mathrm{FRET}}=1-\frac{F_{\mathrm{D}}^{*}}{F_{\mathrm{D}}},
$$
cence intensity in the presence of the acceptor, and $F_{\mathrm{D}}$ is its fluorescence intensity in the absence of acceptor.

TIRF images of a cell coexpressing CNGB3N-EGFP-F and CNG-modulin-HaloTag-TMR are presented in Figure $3 \mathrm{~A}$. Shown are images of EGFP and TMR fluorescence before and after TMR bleaching. The TMR (acceptor) image demonstrates the effectiveness of bleaching: emission intensity was higher before than after bleaching; mean intensity ratios were $2.8 \pm 1.0$ (mean $\pm \mathrm{SD}$ ) (Table 1$)$. The EGFP (donor) fluorescence image where $E_{\mathrm{FRET}}$ is FRET efficiency, $F_{\mathrm{D}}^{*}$ is the donor emission fluores- 
demonstrates efficient FRET: emission intensity was less before than after bleaching. Mean FRET efficiency (Eq. 1) was $0.30 \pm 0.08$ (Table 1 ).

As a control, we also measured $E_{\mathrm{FRET}}$ between EGFP and TMR in cells coexpressing protein pairs not expected to interact with each other: either the CNG-modulinHaloTag-TMR with EGFP-F alone or CNGB3N-EGFP-F with HaloTag-TMR alone. For purposes of illustration, we present in Figure $3 B$ images of a cell coexpressing CNGB3N-EGFP-F with HaloTag-TMR alone, before and after bleaching. The TMR image demonstrates the effectiveness of bleaching since the emission intensity nearly disappears. The EGFP image, in contrast, hardly changes in intensity upon TMR bleaching. Measurements of FRET efficiency showed mean $E_{\mathrm{FRET}}$ was $0.045 \pm$ $0.024(n=5)$ in cells expressing CNGB3N without CNG-modulin and $0.044 \pm 0.021$ $(n=4)$ in those expressing CNG-modulin without CNGB3N, indicating essentially no interaction in these negative controls. Thus, energy transfer between EGFP and TMR occurs only when the fluorophores are expressed in fusion with CNGB3N and CNGmodulin, affirming that there is specific binding interaction between the $\mathrm{N}$-terminal cytoplasmic domain of CNGB3 and soluble CNG-modulin.

CNG-modulin protein is expressed in single and twin cone photoreceptors and is undetectable in rods

If CNG-modulin is a modulator of cone photoreceptor CNG channels, it must be expressed in these cells. We investigated the cellular expression and localization of CNG-modulin using single-cell RT-PCR and immunohistochemistry in frozen retinal slices.

To determine whether CNG-modulin mRNA is expressed in bass cones, we performed RT-PCR assays with individual, isolated single and twin cone photoreceptors. Single-cell PCR with CNG-modulin-specific primers yielded a single product of size and sequence identical to that obtained with the same primers when purified cloned CNG-modulin DNA was used as a template (positive control) (Fig. 4A). Similar results were obtained in seven single and two twin cones. The cell-bathing Ringer's solution in the chamber was exhaustively exchanged before collecting the individual cells to assure that the small collected volume was not contaminated by mRNA that originated elsewhere in the retinal tissue. Nonetheless, as a negative control to confirm the absence of contaminating mRNA, we performed RT-PCR with Ringer's sample collected next to an attached single cone but free of any cells. Control samples did not yield any detectable DNA when processed identically to a cell-containing sample (Fig. 4A). Thus, the results with positive and negative samples show that CNG-modulin mRNA transcript is certainly present in both single and twin photoreceptors.

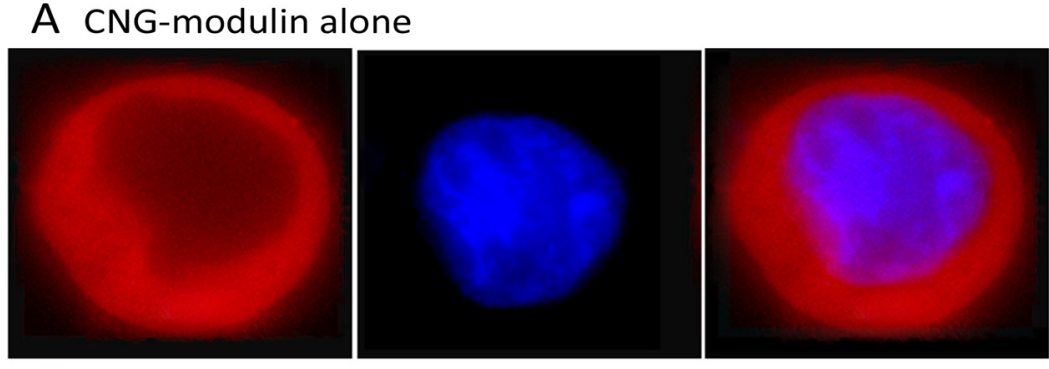

\section{B CNG-modulin or CNGB3N alone}
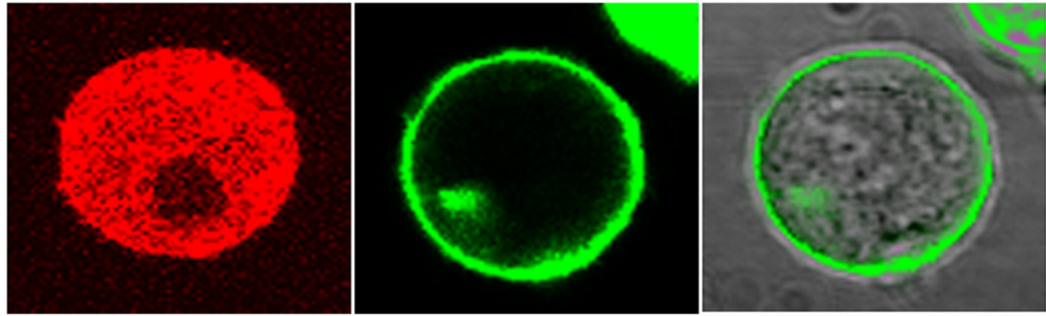

C CNG-modulin and CNGB3N co-expressed
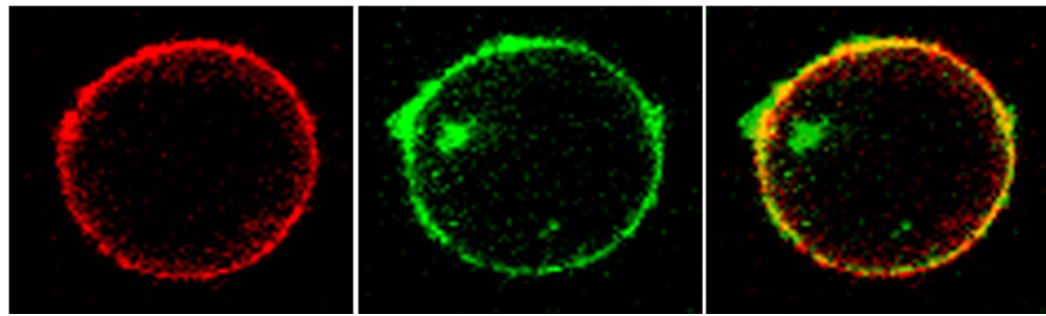

Figure 2. Images of tsA201 cells expressing fluorescently labeled CNG-modulin (HaloTag-TMR label; red) and CNGB3N (EGFP-F 列 excluded from the nucleus. $\boldsymbol{B}$, Left, A confocal fluorescence image of a cell that expresses CNG-modulin-HaloTag-TMR alone. The image complements the information in $\boldsymbol{A}$ and shows that the fluorescent protein is distributed throughout the cytoplasm and rotein is anchored at the plasma membrane by a farnesylation signal. This is affirmed in $\boldsymbol{B}$ (right) a superimposition of the middle

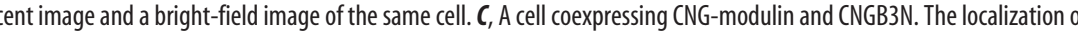
emonstrates that in the presence of CNGB3N-EGFP-F, the CNG-modulin-HaloTag-TMR does not distribute homogeneously throughout the cytoplasm but localizes at the plasma membrane, indicating that the proteins interact with each other.

To evaluate the retinal distribution of CNG-modulin and confirm its presence in cones, we produced polyclonal antiCNG-modulin antibodies by immunizing rabbits with a conjugate of a peptide corresponding to amino acids $77-87$ (Fig. 1 B). Affinity-purified antibody specifically binds to CNG-modulin. This is illustrated in Figure $4 B$, an immunoblot in which antibody binding was tested on lysate of whole bass retina separated by SDS-PAGE. The antibody recognized a single protein band of apparent molecular mass $31 \mathrm{kDa}$, a band we identify as CNGmodulin because its molecular mass is consistent with that predicted by the amino acid composition and measured for purified recombinant CNG-modulin separated by SDS-PAGE (Fig. 1A).

Figure $5 A$ represents the image of a retinal section incubated with the anti-CNG-modulin antibody and then processed with a fluorescent secondary antibody to determine the cellular localization of CNG-modulin. The antibody labeled both the inner and outer segments of single and twin cone photoreceptors (Fig. $5 \mathrm{~A}$, inset, left), but not the rod outer segments present in the same layer. The photoreceptor layer (PL) consists of the photoreceptor inner and outer segments. The outer nuclear layer (ONL) is identified by the blue fluorescence of nuclei stained with Hoechst 
CNGB3 and CNG-modulin Before

After

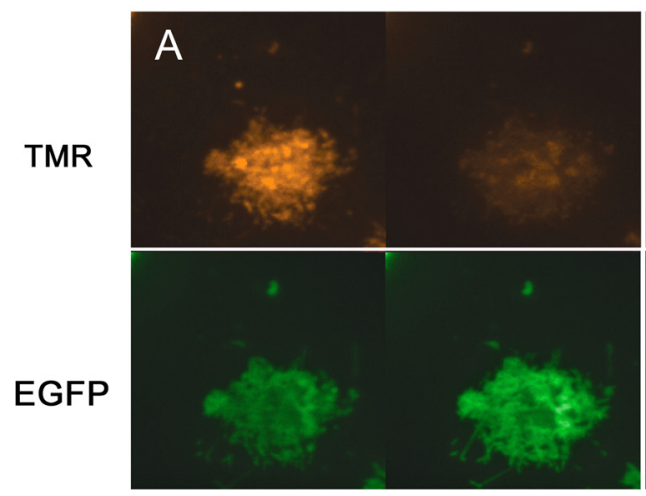

CNGB3 without CNG-modulin Before

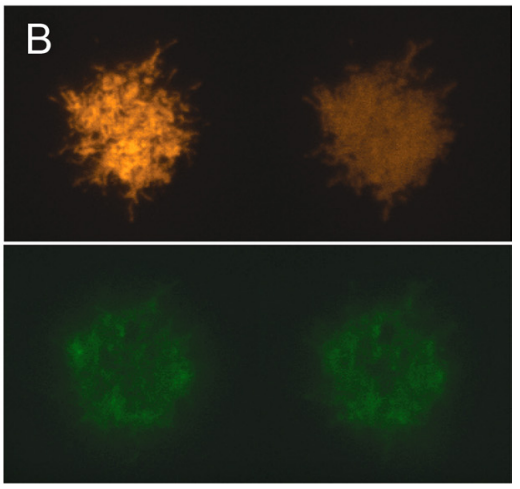

Figure 3. $\boldsymbol{A}$, TIRF images of the same cell coexpressing CNGB3N-EGFP-F and CNG-modulin-HaloTag-TMR. The fluorescence emission intensity of TMR (orange) or EGFP (green) is monitored through distinct optical channels. Images were captured before (left) and after (right) photobleaching TMR. Efficient photobleaching is demonstrated by the loss of TMR fluorescence intensity. Upon TMR bleaching, EGFP fluorescence intensity increased. This fluorescence enhancement demonstrates efficient FRET between the two fluorophores. Quantitative analysis of FRET efficiency in this and other cells is detailed in Table 1. $\boldsymbol{B}$, TIRF images of a cell coexpressing noninteracting fluorescent proteins: CNGB3N-EGFP-F and HaloTag-TMR alone (without CNG-modulin). Images were captured before (left) and after (right) TMR photobleaching. Efficient TMR photobleaching is demonstrated by the loss of emission intensity by this dye. Upon TMR bleaching, EGFP fluorescence was unchanged, indicating that FRET does not occur between protein pairs not expected to bind each other.

Table 1. FRET efficiency in TIRF images of cells expressing CNGB3N-EGFP (donor) and CNG-modulin-HaloTag-TMR (acceptor)

\begin{tabular}{|c|c|c|c|c|c|}
\hline \multirow[b]{2}{*}{ Cell } & \multicolumn{2}{|c|}{$\begin{array}{l}\text { Fluorescence of CNG- } \\
\text { modulin-Halo-Tag-TMR }{ }^{a}\end{array}$} & \multicolumn{2}{|c|}{$\begin{array}{l}\text { Fluorescence of } \\
\text { CNGB3N-EGFP-F }^{a}\end{array}$} & \multirow[b]{2}{*}{$E_{\mathrm{FRET}}^{b}$} \\
\hline & $\begin{array}{l}\text { Before TMR } \\
\text { bleaching }\end{array}$ & $\begin{array}{l}\text { After TMR } \\
\text { bleaching }\end{array}$ & $\begin{array}{l}\text { Before TMR } \\
\text { bleaching }\left(F_{D}^{*}\right)\end{array}$ & $\begin{array}{l}\text { After TMR } \\
\text { bleaching }\left(F_{D}\right)\end{array}$ & \\
\hline 1 & 18373 & 6430 & 15813 & 27664 & 0.43 \\
\hline 2 & 13748 & 6056 & 11895 & 16459 & 0.28 \\
\hline 3 & 29385 & 16176 & 9961 & 13129 & 0.24 \\
\hline 4 & 7424 & 1774 & 20805 & 28104 & 0.26 \\
\hline Mean \pm SD & & & & & $0.30 \pm 0.08$ \\
\hline
\end{tabular}

${ }^{a}$ Data are shown for the mean gray level (in a 16 bit scale) measured over the area of the fluorescent cell image, corrected by subtracting the gray level of an identical area measured over the background.

${ }^{b}$ The efficiency of energy transfer between EGFP and TMR is quantified by measuring the emission intensity of EGFP fluorescence before and after bleaching TMR (Eq. 1).

33342 dye (Fig. 5A-C1). Inner and outer segments are distinguished by their distinct structure in a bright-field image of the retinal section (Fig. 5C1). Cone inner and outer segments are readily identified by their characteristic structure. The slender $(\sim 1 \mu \mathrm{m}$ in diameter) rod outer segments are intermingled with the cone outer segments. The presence of rod and cone outer segments alongside each other is made evident in Figure 5C2. This is the same section as in Figure 5C1, but imaged under fluorescence light to reveal the localization of rod outer segments labeled with a rod-specific marker: an antibody against rod transducin $\alpha$ subunit $\left(\mathrm{G}_{\alpha \mathrm{t} 1}\right)$. The space occupied by single and twin cone photoreceptors in the outer-segment layer appears as dark "holes" in the fluorescence micrograph (Fig. 5C2) because the anti-rod $\mathrm{G}_{\alpha \mathrm{t} 1}$ antibody does not stain cone outer segments. More importantly, the anti-CNG-modulin antibody does not stain rod outer segments to any detectable level. The absence of detectable antibody binding to rods serves as an additional control for the antibody specificity since rods and cones share the same major structural and housekeeping proteins.

As an additional control for the immunohistochemical studies, we show in Figure $5 B$ the fluorescence image of a retinal section processed just as the section illustrated in Figure $6 \mathrm{~A}$, but

omitting incubation with the primary anti CNG-modulin antibody. When the primary antibody was omitted, the fluorescent secondary antibody did not bind cone outer segments which, therefore, did not fluoresce at all.

Overall, the experimental and control immunohistochemical results demonstrate that CNG-modulin is expressed in both inner and outer segments of single and twin cone photoreceptors, but it is not detected in rod cells.

\section{CNG-modulin mRNA is expressed in} several tissues in addition to the retina We used RT-PCR technology to examine the tissue-specific expression of $\mathrm{CNG}$ modulin mRNA (Fig. 6). In addition to retina, transcripts were expressed in some tissues, but were not ubiquitous. While the apparent expression level was highest in the retina, CNG-modulin mRNA was also detected in inner ear, brain, olfactory rosette, gills, kidney, and spleen. CNG-modulin mRNA was below detectable levels in the intestine, gonad, liver, muscle, and heart.

Recombinant CNG-modulin introduces $\mathrm{Ca}^{2+}$-dependent modulation of ligand sensitivity of CNG ion channels in cone outer-segment membrane patches quantitatively similar to that in intact cones

We tested the effect of CNG-modulin on the ligand sensitivity of cGMPdependent currents in membrane patches detached from bass single cone outer segments. Recombinant CNG-modulin was expressed in E. coli and purified as described above.

Ca-dependent ligand sensitivity modulation of the channels is robust only in intact cone outer segments in both mammals and nonmammal vertebrates (Rebrik and Korenbrot, 1998, 2004). The mere act of detaching a membrane patch from the cone outer segment causes almost total loss of $\mathrm{Ca}^{2+}$-dependent CNG channel modulation, even if patches are detached in the presence of a high concentration of $\mathrm{Ca}^{2+}(20 \mu \mathrm{M})$ (Hackos and Korenbrot, 1997; Haynes and Stotz, 1997). This indicates the modulator is not irreversibly bound to the channel protein in native membranes; it is soluble and lost from membrane fragments by simple dilution. Moreover, any small amount of modulator that may remain associated with an inside-out membrane patch is removed by washing the patch cytoplasmic surface with a divalent cation-free salt solution (containing EDTA/EGTA) (Hackos and Korenbrot, 1997). To avoid confusing the regulatory effects of recombinant CNG-modulin with those of the potential small amount of endogenous modulator that might remain associated with a membrane patch, we started all experiments reported here by first washing the membrane patch with a divalent cation-free solution.

In the presence of recombinant CNG-modulin, the ligand sensitivity of CNG channels in cone membrane patches was modulated by $\mathrm{Ca}^{2+}$ in a manner quantitatively similar to that observed in intact cells. In Figure 7, we show cGMPdependent currents measured at $-40 \mathrm{mV}$ all in the same cone outer-segment membrane patch. Following the exposure to a divalent cation-free solution, we measured cGMP-activated currents in the presence of $90 \mathrm{nM} C N G-m o d u l i n$ and $20 \mu \mathrm{M} \mathrm{Ca}{ }^{2+}$ 
A

\section{Single cell RT-PCR}

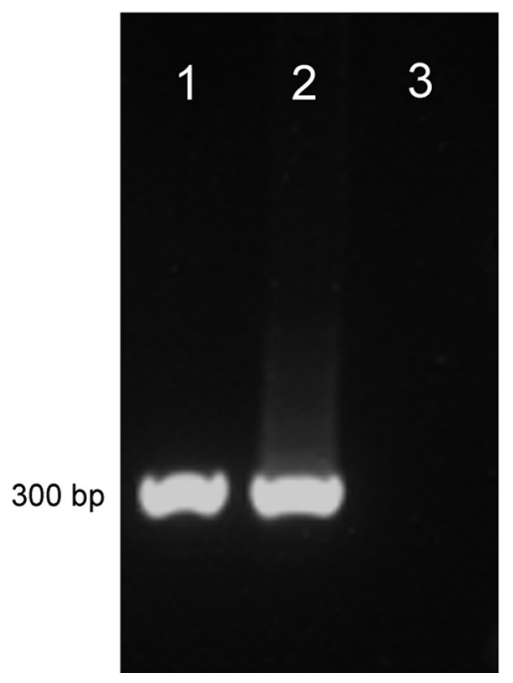

B

\section{Immunoblot}

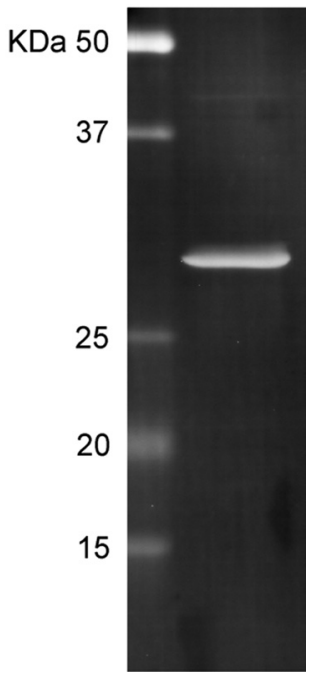

Figure 4. $\quad \boldsymbol{A}, \mathrm{PCR}$ products separated by gel electrophoresis. Reactions were performed with identical primers on three different templates: Lane 1, RT reaction product of one single cone. Lane 2, Purified CNG-modulin CDNA. Lane 3, Negative control, a cell-free sample of bathing Ringer's solution identical in volume to the sample that contained one single cone and collected near a photoreceptor in the incubation chamber. The individual single cone and the CNGmodulin CDNA samples yielded single PCR products of identical size and sequence. The cell-free sample did not yield any $P C R$ product. $\boldsymbol{B}$, Western blot of striped bass retina lysate probed with antibody specific to CNG-modulin. The anti-CNG-modulin antibody labels only one protein band of apparent molecular mass consistent with that of CNG-modulin. The apparent molecular mass of the band labeled by anti CNG-modulin is $31 \mathrm{kDa}$.

(Fig. 7A). The patch was then washed free of $\mathrm{Ca}^{2+}$, and cGMP sensitivity tested again in the presence of $90 \mathrm{~nm} C N G$-modulin in a $\mathrm{Ca}^{2+}$-free solution (Fig. $7 B$ ). Finally, the patch was tested in solutions free of both $\mathrm{Ca}^{2+}$ and CNG-modulin (Fig. 7C). The cGMP dependence of the steady-state current amplitude under each condition is well described by the Hill equation:

$$
I(c G M P)=I_{\max } \frac{c G M P^{n}}{c G M P^{n}+K_{c G}^{n}},
$$

where $I_{\max }$ is the maximum current measured in that patch under the conditions tested, $c G M P$ is the concentration, $K_{\mathrm{cG}}$ is the cGMP concentration at which current is half its maximum value, and $n$ is the Hill coefficient, which denotes cooperativity. The values of $K_{\mathrm{cG}}$ and $n$ were Ca dependent in the presence of CNGmodulin (Fig. 7E).

The quantitative features of the CNG-modulin-dependent modulation averaged over measurements in different membrane patches are shown in Table 2. The ratio $K_{\mathrm{cG}}\left(20 \mu \mathrm{M} \mathrm{Ca}^{2+}, 90 \mathrm{nM}\right.$ CNG-modulin $) / K_{\mathrm{cG}}\left(0 \mathrm{Ca}^{2+}, 90 \mathrm{nM}\right.$ CNG-modulin $)$ is 3.65, within experimental uncertainty, the same as that measured in intact cone outer segments and mediated by the authentic modulator (Table 2).

\section{$\mathrm{Ca}^{2+}$ dependence of CNG-modulin-mediated CNG channel} modulation is quantitatively similar to that in intact cones If CNG-modulin is the authentic CNG channel modulator, then the Ca-dependent change in CNG channel ligand sensitivity measured in its presence should reproduce the $\mathrm{Ca}^{2+}$ dependence measured in intact cones. We measured cGMP-activated currents in cone outer-segment membrane patches at various $\mathrm{Ca}^{2+}$

concentrations (between 0 and $20 \mu \mathrm{M}$ ) in the presence of $90 \mathrm{nM}$ CNG-modulin and $200 \mu \mathrm{M}$ cGMP (Fig. 7D). The test cGMP concentration of $200 \mu \mathrm{M}$ was selected because this concentration is below the saturating level of cGMP in both $\mathrm{Ca}^{2+}$-free and $20 \mu \mathrm{M}$ $\mathrm{Ca}^{2+}$ solutions. In every patch studied, cGMP-dependent current decreased as the free $\mathrm{Ca}^{2+}$ concentration increased from 0 to $20 \mu \mathrm{M}$, but the absolute value of the maximum cGMP-dependent current amplitude varied from patch to patch. This variance simply reflects the well-known fact that the surface area of each membrane patch, and therefore the total number of channels sampled, is not constant, a characteristic of the experimental method. In 10 different membrane patches, the current activated by $200 \mu \mathrm{M}$ cGMP in a $\mathrm{Ca}^{2+}$-free solutions in the presence of $90 \mathrm{~nm}$ CNGmodulin ranged between 140 and 740 pA. Regardless of absolute magnitudes, however, the ratio of maximum $\left(\mathrm{Ca}^{2+}\right.$-free $)$ to minimum $\left(20 \mu \mathrm{M} \mathrm{Ca}^{2+}\right)$ current amplitudes was comparable among the patches, $2.95 \pm 0.20$.

To quantitatively analyze and compare results among the many patches, we normalized current amplitude. In each patch, we determined the maximal $\mathrm{Ca}^{2+}$-dependent current by subtracting the amplitude measured at $20 \mu \mathrm{M} \mathrm{Ca}^{2+}$ from that measured in the absence of $\mathrm{Ca}^{2+}$. We then normalized current amplitude by dividing the $\mathrm{Ca}^{2+}$-dependent current at every $\mathrm{Ca}^{2+}$ concentration tested by the maximum $\mathrm{Ca}^{2+}$-dependent current measured in the same patch. For the 10 patches tested, normalized mean current amplitude as a function of $\mathrm{Ca}^{2+}$ is shown in Figure $7 F$. Data points are well fit by an inverse Michaelis-Menten function:

$$
\frac{I(\mathrm{Ca})}{I_{\max }}=\frac{1}{1+C a / K_{\mathrm{Ca}}},
$$

where $I(\mathrm{Ca}) / I_{\max }$ is the normalized mean current amplitude, $\mathrm{Ca}$ is the $\mathrm{Ca}^{2+}$ concentration, and $K_{\mathrm{cG}}$ is the $\mathrm{Ca}^{2+}$ concentration at which current is half its maximum amplitude. This is the same function that describes $\mathrm{Ca}^{2+}$ dependence of current enhancement in the electropermeabilized bass single cone (Rebrik and Korenbrot, 1998).

Remarkably, the $K_{\mathrm{Ca}}$ value that describes the $\mathrm{Ca}^{2+}$ dependence of ligand sensitivity mediated by the authentic modulator in structurally intact cone outer segments, $857 \pm 68 \mathrm{~nm}$ (Rebrik et al., 2000), is statistically indistinguishable from that measured in detached membrane patches in the presence of CNG-modulin, $825 \pm 73 \mathrm{nM}$ $(p<0.01$ two-tailed Student's $t$ test); that is, CNG-modulin modulates the cGMP sensitivity of native channels to an extent and with a $\mathrm{Ca}$ dependence indistinguishable from that of the endogenous modulator.

\section{CNG-modulin is a $\mathrm{Ca}^{2+}$-binding protein}

CNG-modulin protein lacks conventional consensus $\mathrm{Ca}^{2+}$ binding domain motifs such as $\mathrm{C}_{2}, \mathrm{CBD} 1$, or EF hands. However, there are $>80$ families of $\mathrm{Ca}^{2+}$-binding structural motifs, some of them containing only a few hundred proteins, and even the conventional motifs represent only a limited fraction of all $\mathrm{Ca}^{2+}$ binding proteins (Muranyi and Finn, 2006). Therefore, we undertook to directly determine the $\mathrm{Ca}^{2+}$-binding features of CNG-modulin using two different methods: an assay of $\mathrm{Ca}^{2+}$ binding to protein immobilized on a PVDF membrane using the fluorescent $\mathrm{Ca}^{2+}$ indicator Quin2 (Tatsumi et al., 1997) and an investigation of the effects $\mathrm{Ca}^{2+}$ on the intrinsic fluorescence of aromatic amino acids in the protein (Lin et al., 2008).

In the first method, developed as a nonradioactive alternative to binding ${ }^{45} \mathrm{Ca}^{2+}$, recombinant $\mathrm{CNG}$-modulin was subjected to SDS-PAGE and electroblotted onto a PVDF membrane. The 


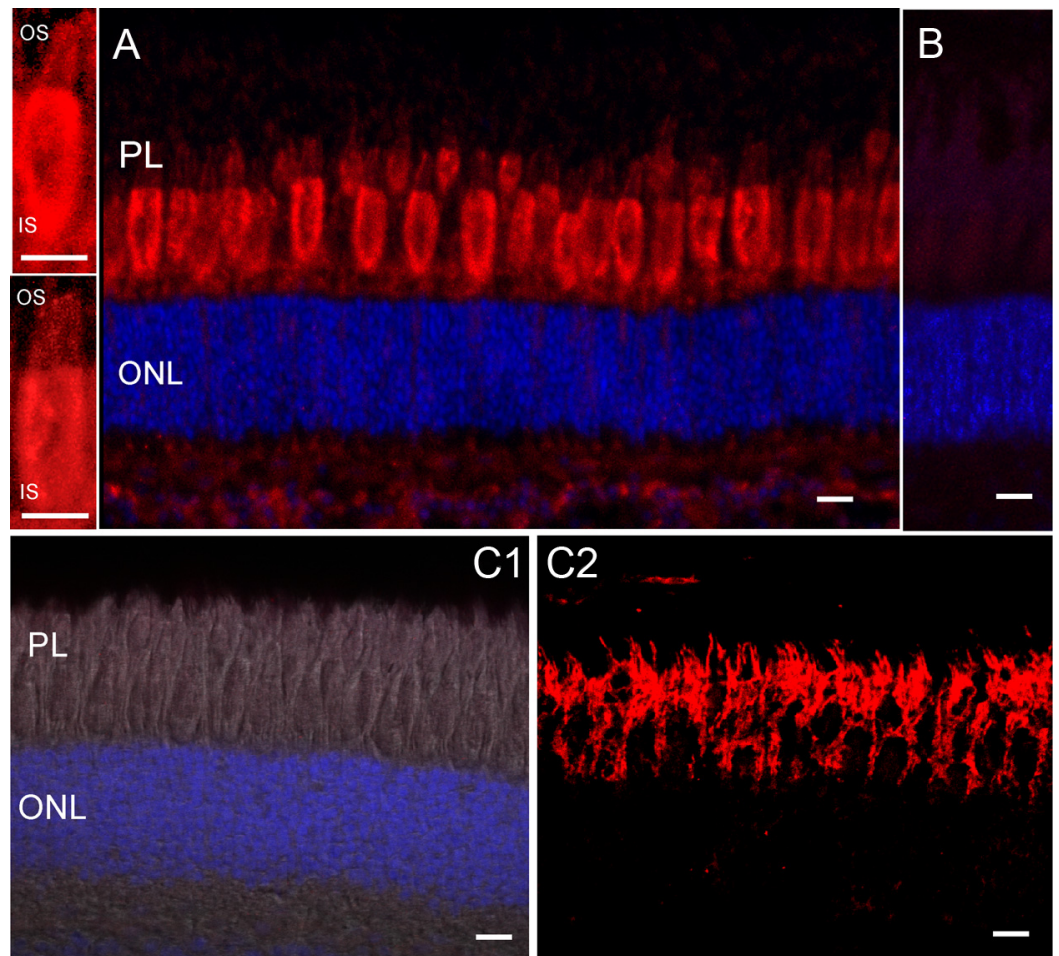

Figure 5. Confocal immunofluorescent images of striped bass retinal cross-sections. Retinal layers ONL and PL are shown. $\boldsymbol{A}$, The photoreceptor layer of a retina section reacted with anti-CNG-modulin antibody, in turn labeled with a red fluorescent secondary antibody. The section was counterstained with Hoechst 33342 dye to identify cell nuclei (blue). The inner (IS) and outer segments $(O S)$ of both single and twin cone photoreceptors are strongly fluorescent (enlarged images on the left), indicating that they express CNG modulin. $\boldsymbol{B}$, A sequential section of the same retina shown in $\boldsymbol{A}$ and handled in every respect the same as $\boldsymbol{A}$ but omitting the anti-CNG-modulin antibody. In the absence of the antibody, cone photoreceptors do not fluoresce, a negative contro to confirm the specificity of CNG-modulin cellular localization. C1, C2, Images of the same retinal section reacted with anti- $G_{\alpha t 1}$ antibody, a rod outer-segment-specific marker. The primary antibody is labeled with a red fluorescent secondary antibody. C1, An overlay of a bright-field image and a fluorescent image captured to reveal the nuclei counterstained with Hoechst 33342 (blue). C2 A confocal fluorescent image that shows the location of rod outer segments labeled with anti- $\mathrm{G}_{\alpha \mathrm{t} 1}$ antibodies, a specific rod marker. Together, images in C 1 and $C 2$ demonstrate that rod outer segments are comingled with the cone photoreceptors in these retinal sections. Scale bars: $10 \mu \mathrm{m}$.

\section{CNG-modulin}

\begin{tabular}{|c|c|c|c|c|c|c|c|c|c|c|c|}
\hline $\mathbf{G}$ & 1 & $\mathrm{~L}$ & $\mathrm{~K}$ & $S$ & B & $\mathrm{H}$ & 0 & G & $M$ & I & $\mathrm{R}$ \\
\hline O & $\mathrm{n}$ & $\mathbf{i}$ & $\mathbf{i}$ & $p$ & $r$ & e & I & $\mathbf{i}$ & $\mathbf{u}$ & $\mathrm{n}$ & $\mathrm{e}$ \\
\hline $\mathrm{n}$ & $\mathbf{t}$ & $\mathbf{V}$ & d & 1 & $a$ & $a$ & $\mathbf{f}$ & I & $\mathrm{S}$ & $\mathrm{n}$ & $\mathbf{t}$ \\
\hline a & $\mathrm{e}$ & e & $\mathrm{n}$ & e & $\mathbf{i}$ & $r$ & $a$ & 1 & C & e & i \\
\hline $\mathrm{d}$ & $\mathrm{S}$ & $r$ & $\mathrm{e}$ & e & $\mathrm{n}$ & $\mathbf{t}$ & C & & I & $r$ & $\mathrm{n}$ \\
\hline $\mathrm{S}$ & $t$ & & $y$ & $\mathrm{n}$ & & & $t$ & & $\mathrm{e}$ & $\mathrm{E}$ & $a$ \\
\hline & $\mathbf{i}$ & & & & & & 0 & & & a & \\
\hline & $\mathrm{n}$ & & & & & & $r$ & & & $r$ & \\
\hline & e & & & & & & $y$ & & & 1 & \\
\hline
\end{tabular}

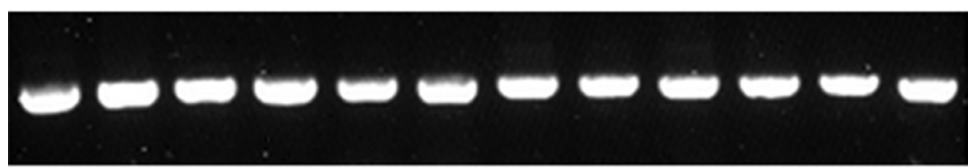

$\beta$ actin

Figure 6. RT-PCR products obtained from various striped bass tissues, as labeled. PCR primers were used to amplify either CNG-modulin mRNA (top) or $\beta$-actin (bottom). The intensity of all $\beta$-actin bands was within $\pm 5 \%$ of the mean. membrane was incubated with $\mathrm{Ca}^{2+}$ and then washed in $\mathrm{Ca}^{2+}$-free buffer to remove all nonbound $\mathrm{Ca}^{2+}$. We then assessed whether $\mathrm{Ca}^{2+}$ remained bound to the immobilized protein by reacting the blot with Quin2, a fluorescent $\mathrm{Ca}^{2+}$ indicator that interacts strongly with $\mathrm{Ca}^{2+}$ associated with immobilized $\mathrm{Ca}^{2+}$-binding proteins (Bryant, 1985). Figure $8 A$ is an image of a protein blot captured under Quin2 fluorescence excitation light. The membrane image reveals strong fluorescence of the CNG-modulin protein band, indicating that the protein binds $\mathrm{Ca}^{2+}$. As a positive control, the membrane blot also included calmodulin, which, as expected, also fluoresced. Furthermore, the molecular weight standards immobilized in the same blot included muscle myoglobin, an $\mathrm{Fe}^{3+}$-containing protein, which also fluoresced because Quin2 fluorescence is enhanced by multivalent cations as well (Jones et al., 1992). Other molecular mass standards were not metal-binding proteins and did not fluoresce, serving as a negative control.

To quantitatively characterize the $\mathrm{Ca}^{2+}$ binding, we measured the intrinsic fluorescence of recombinant $\mathrm{CNG}$-modulin in the presence of varying concentrations of either $\mathrm{Ca}^{2+}$ or $\mathrm{Mg}^{2+}$. CNG-modulin contains seven tyrosine residues and no tryptophan. It is well established that in $\mathrm{Ca}^{2+}$-binding proteins the fluorescence emission intensity of some amino acids changes upon $\mathrm{Ca}^{2+}$ binding, presumably because of bindingdependent conformational changes (Lin et al., 2008). Figure $8 B$ presents typical CNG-modulin fluorescence emission spectra excited by $280 \mathrm{~nm}$ light at various concentrations of either $\mathrm{Ca}^{2+}$ or $\mathrm{Mg}^{2+}$. The emission spectra exhibit a single peak at $\sim 303 \mathrm{~nm}$, characteristic of tyrosine intrinsic fluorescence (Teale and Weber, 1957). $\mathrm{Ca}^{2+}$ causes a concentrationdependent emission intensity enhancement above $100 \mathrm{nM} \mathrm{Ca}^{2+}$. In each of 15 different experiments, we measured emission intensity at $303 \mathrm{~nm}$ in the absence of $\mathrm{Ca}^{2+}$, at $20 \mu \mathrm{M} \mathrm{Ca}^{2+}$, and at various concentrations in between. Normalized fluorescence enhancement between $100 \mathrm{~nm}$ and $20 \mu \mathrm{M}$ depends on $\mathrm{Ca}^{2+}$ in a manner well described by a Hill equation (Fig. 8B):

$$
\frac{F_{\min }}{F_{\max }}=\frac{C a^{n}}{C a^{n}+K_{\mathrm{Ca}}^{n}},
$$

where $F_{\min }$ and $F_{\text {max }}$ are the limiting values of fluorescence enhancement, $K_{\mathrm{Ca}}$ is the $\mathrm{Ca}^{2+}$ affinity constant, and $n$ is the Hill coefficient. Mean values in our exper- 

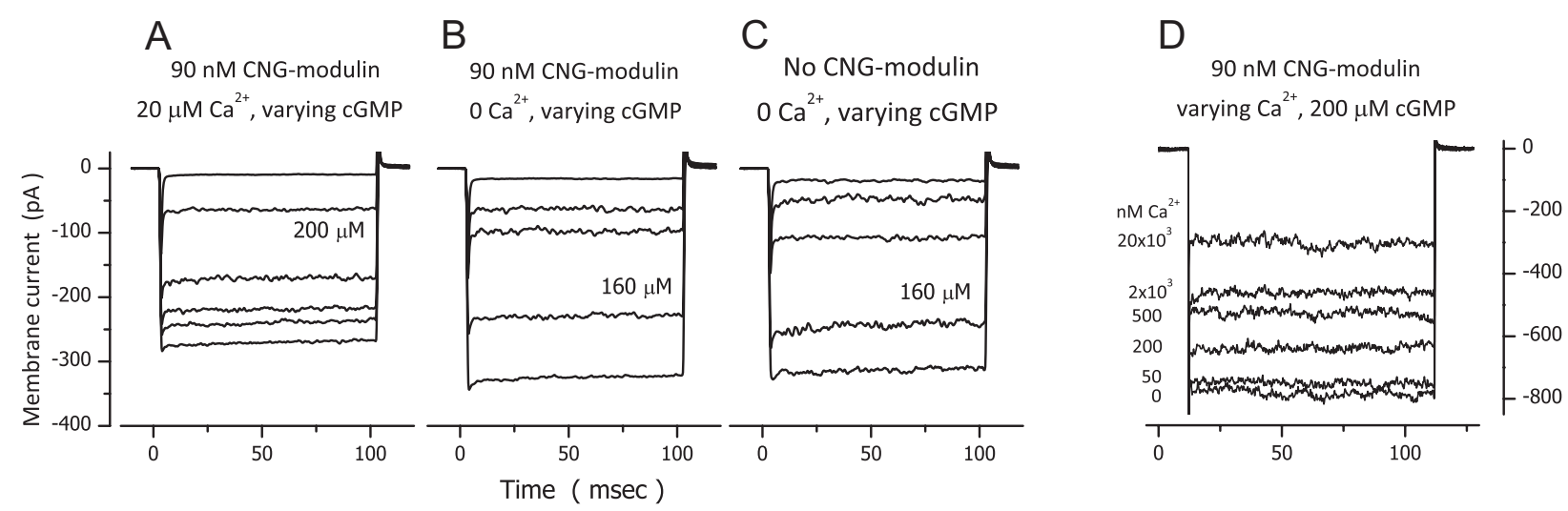

$E$
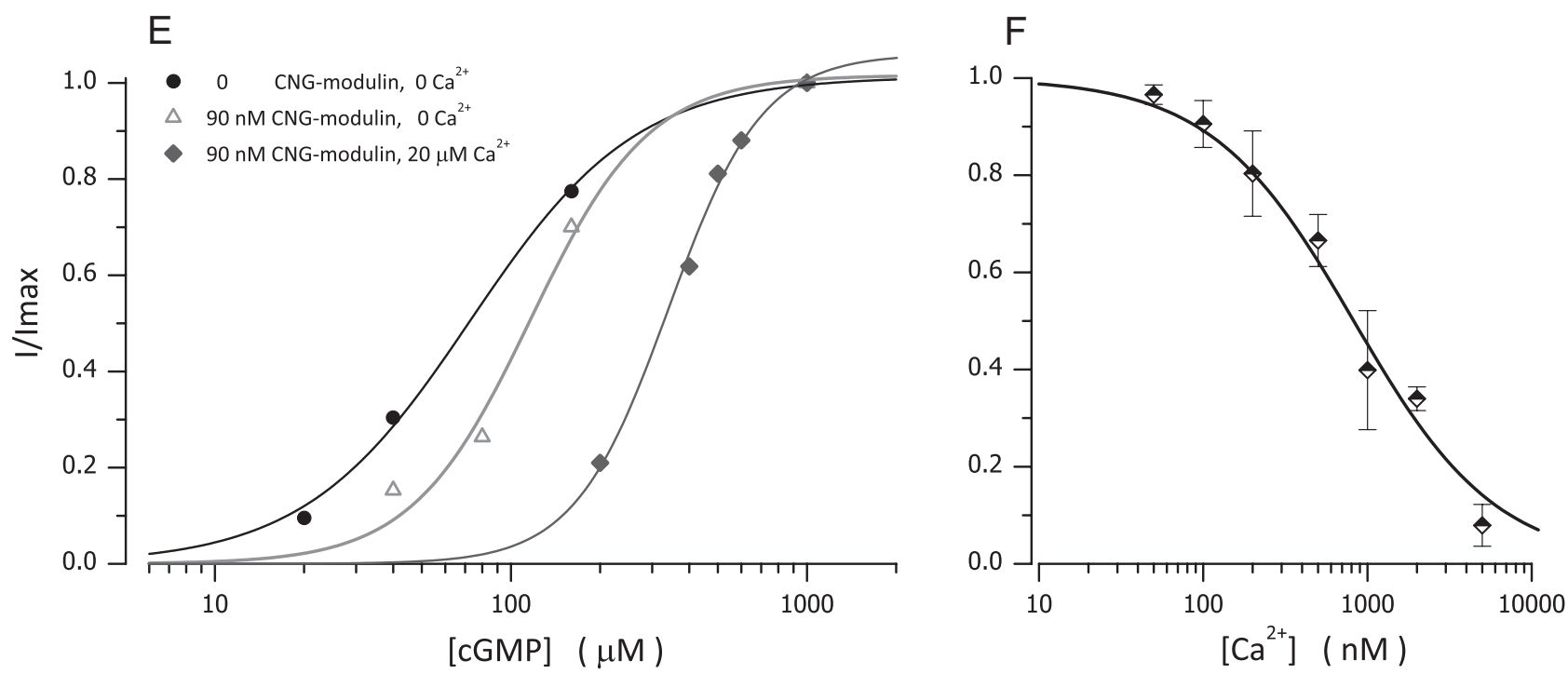

Figure 7. Voltage-clamped currents measured in membrane patches detached from bass single cone outer segments. Currents were activated by $100 \mathrm{~ms}$ voltage steps to $-40 \mathrm{mV}$. $A-C$, G GMP-dependent currents measured in the same membrane patch while its cytoplasmic membrane surface was bathed with various combinations of $90 \mathrm{~nm} \mathrm{recombinant} \mathrm{CNG}$-modulin and $\mathrm{Ca}^{2+}$ at either 0 or $20 \mu \mathrm{m} \mathrm{concentration,} \mathrm{as} \mathrm{labeled.} \mathrm{CGMP}$ concentrations tested were as follows: 0,200,400,500,600 and $1000 \mu \mathrm{m}(\boldsymbol{A}) ; 0,40,80,160$ and $1000 \mu \mathrm{m}(\boldsymbol{B})$; and 0,20,40, 160 and $1000 \mu \mathrm{m}$ (C).D, CGMP-dependent currents measured while the cytoplasmicmembrane surface was bathed with $90 \mathrm{~nm} C \mathrm{CNG}$-modulin and $200 \mu \mathrm{m} \mathrm{CGMP} \mathrm{at} \mathrm{varying} \mathrm{Ca}^{2+}$ concentration between 0 and $20 \mu \mathrm{M}$, as labeled. E, Normalized membrane currentmeasured from the data in the $A-C$ as a function of $\mathrm{CGMP}$ concentration. The continuous lines are the Hill function (Eq. 2) optimally fit to the data. The values of the adjustable parameters that best fit the data were $K_{\mathrm{cG}}=73.74 \mu \mathrm{M}$ and $n=1.49 \mathrm{in}$ the absence of $\mathrm{Ca}^{2+}$ and CNG-modulin, $K_{\mathrm{CG}}=107.67 \mu \mathrm{mand} n=2.2 \mathrm{at} 0 \mathrm{nmCa}{ }^{2+}$ and $90 \mathrm{~nm} C \mathrm{CNG}$-modulin, and $\mathrm{K}_{\mathrm{CG}}=321.59 \mu \mathrm{mand} n=3.04$ at $20 \mu \mathrm{m} \mathrm{Ca}^{2+}$ and $90 \mathrm{~nm}$ CNG-modulin. Theparameters ofthechannelmodulationby CNG-modulin are compared with parameters of modulation by the endogenous modulator in Table $2 . F$, Normalized membrane current in the presence of $90 \mathrm{~nm} \mathrm{CNG-modulin} \mathrm{and} 200 \mu \mathrm{m} \mathrm{CGMP}$ as a function of $\mathrm{Ca}^{2+}$ concentration (mean $\pm \mathrm{SD} ; n=10$ ). The continuous line is an inverse Michaelis-Menten function (Eq.3) optimally fit to the data with $K_{\mathrm{Ca}}=825 \mathrm{~nm}$. Error bars indicate SEM.

Table 2. Adjustable parameters in the Hill equation (Eq. 2) that best fit cGMP-dependent currents in bass cone photoreceptors

\begin{tabular}{|c|c|c|c|}
\hline \multirow[b]{2}{*}{ Test solutions } & \multicolumn{2}{|c|}{ Adjustable parameters $^{a}$} & \multirow[b]{2}{*}{ N } \\
\hline & $K_{\mathrm{CG}}(\mu \mathrm{M})$ & $n$ & \\
\hline \multicolumn{4}{|l|}{ Detached membrane patches } \\
\hline${ }_{b, \mathrm{C}} \mathrm{Ca}^{2+}, 0 \mathrm{CNG}-$ modulin & $58.9 \pm 19.3$ & $1.8 \pm 0.23$ & \\
\hline${ }^{b} 20 \mu \mathrm{M} \mathrm{Ca}^{2+}, 0$ CNG-modulin & $86.1 \pm 18$ & $2.57 \pm 0.34$ & \\
\hline${ }^{\circ} 0 \mathrm{Ca}^{2+}, 90 \mathrm{~nm}$ CNG-modulin & $90.9 \pm 12.6$ & $2.69 \pm 0.49$ & \\
\hline${ }^{2} 20 \mu \mathrm{M} \mathrm{Ca}{ }^{2+}, 90 \mathrm{~nm}$ CNG-modulin & $332.4 \pm 59.9$ & $4.84 \pm 0.94$ & 10 \\
\hline \multicolumn{4}{|l|}{ Intact photoreceptors } \\
\hline${ }^{d} 0 \mathrm{Ca}^{2+}$, authentic modulator & $84.3 \pm 12.6$ & $2.3 \pm 0.37$ & \\
\hline${ }^{d} 20 \mu \mathrm{MCa}^{2+}$, authentic modulator & $335.5 \pm 64.4$ & $2.58 \pm 0.42$ & \\
\hline
\end{tabular}

${ }^{a}$ The mean $\pm S D$ is shown.

${ }^{b}$ Data are from the study by Hackos and Korenbrot (1997).

'Data are from the current study.

${ }^{d}$ Data are from the study by Rebrik and Korenbrot (1998).

iments were $K_{\mathrm{Ca}}=764 \pm 61 \mathrm{nM}$ and $n=2.08(N=15)$; that is, the affinity with which $\mathrm{Ca}^{2+}$ binds to CNG-modulin is similar in value to the $\mathrm{Ca}^{2+}$ sensitivity of channel modulation caused by CNG-modulin.
In contrast to $\mathrm{Ca}^{2+}$, increasing $\mathrm{Mg}^{2+}$ concentration caused only small decrements in fluorescence emission intensity that were detectable only at concentration above $0.5 \mu \mathrm{M}$ and did not saturate at $1 \mathrm{~mm}$, the highest concentration we tested (Fig. $8 \mathrm{~B}$ ). Together, our results indicate CNG-modulin binds $\mathrm{Ca}^{2+}$ with high affinity and specificity.

\section{Discussion}

$\mathrm{Ca}^{2+}$-dependent modulation of ligand sensitivity is a feature common to cyclic nucleotide-gated ion channels in various sensory neurons, although its physiological role is distinct in each cell type. In olfactory sensory neurons, CNG channel modulation was thought to contribute to the $\mathrm{Ca}^{2+}$-dependent adaptation to the repeated or continuous exposure to an odorant (Kurahashi and Shibuya, 1990; Kurahashi and Menini, 1997; Leinders-Zufall et al., 1999); however, OSNs in transgenic mice expressing CNG channels that cannot be modulated by $\mathrm{Ca}^{2+}$ demonstrate normal adaptation to repeated stimuli, but the termination of the receptor potential at the end of stimulus delivery is abnormally slow; that is, channel modulation is required for the rapid recovery of membrane potential when stimulation ceases (Song et al., 2008). 


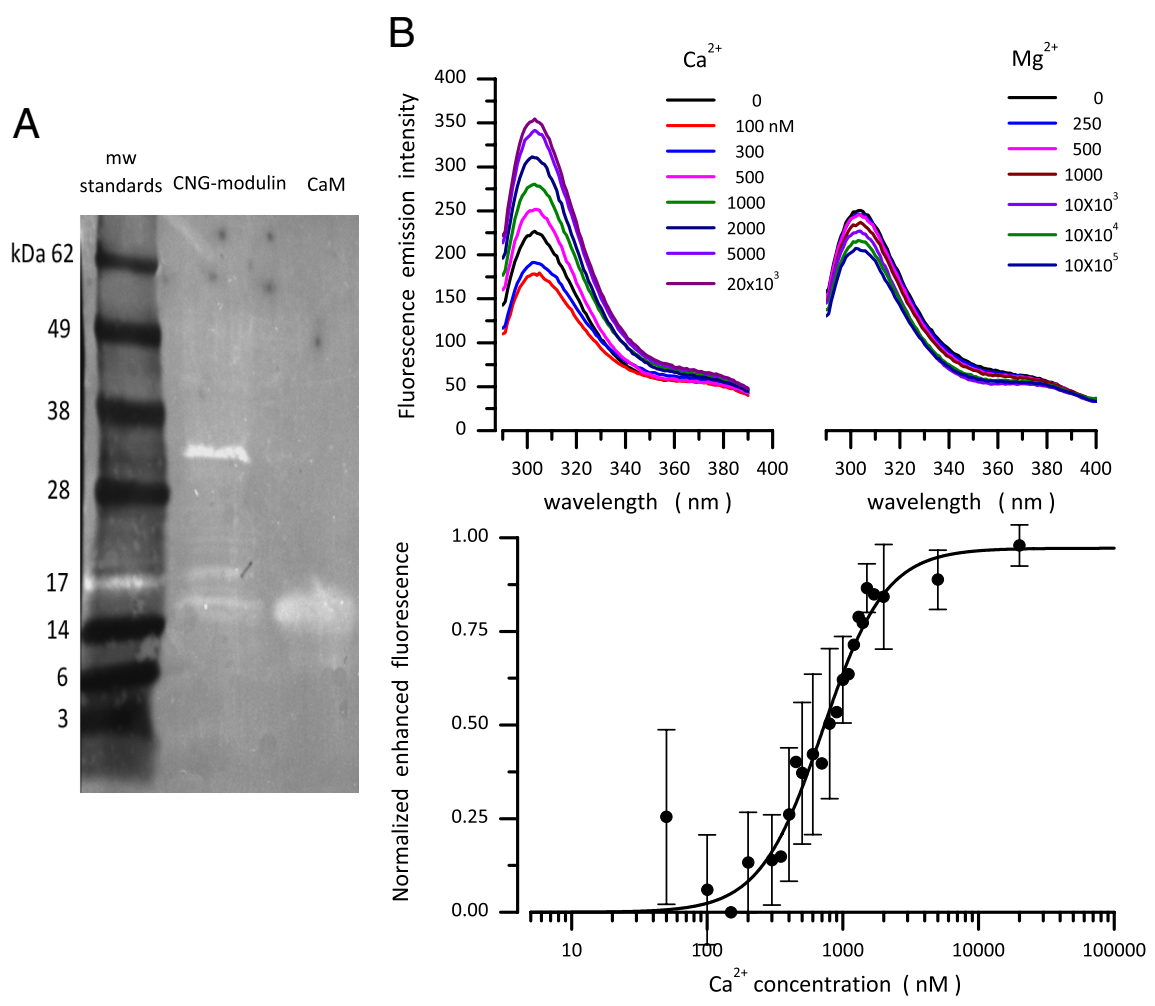

Figure 8. $\quad A, \mathrm{Ca}^{2+}$ binding by CNG-modulin immobilized on the PVDF membrane. Recombinant CNG-modulin, calmodulin, and prestained molecular mass markers (as labeled) were separated by SDS-PAGE, transferred onto PVDF membrane, and treated with $\mathrm{Ca}^{2+}$ and Quin2 as described in Materials and Methods. The bright bands reveal Quin2 fluorescence associated with CNG-modulin (apparent molecular mass, $32.1 \mathrm{kDa}$ ), calmodulin (apparent molecular mass, $16 \mathrm{kDa}$ ), and the $17 \mathrm{kDa}$ muscle myoglobin standard. B, Top, Fluorescence emission spectra (excitation wavelength $280 \mathrm{~nm}$ ) of $0.3 \mu \mathrm{M}$ CNG-modulin solutions containing varying concentrations of either $\mathrm{Ca}^{2+}$ or $\mathrm{Mg}^{2+}$, as labeled. Bottom, Normalized fluorescence emission enhancement at $303 \mathrm{~nm}$ as a function of $\mathrm{Ca}^{2+}$ concentrations (mean $\pm \mathrm{SD} ; n=15$ ). The data are fitted with a Hill function (Eq. 4). Values of the adjustable parameters in the Hill function are $K_{\mathrm{Ca}}=764 \mathrm{~nm}$ and $n=2.08$. In contrast to the effects of $\mathrm{Ca}^{2+}$, increasing $\mathrm{Mg}^{2+}$ concentration reduced the fluorescence intensity with the effect observed in a higher concentration rang.

CNG channel modulation in rod photoreceptors was expected to be of small functional significance because it is small in magnitude, and its $\mathrm{Ca}^{2+}$ dependence would make it relevant only in the response to very bright stimuli (Bauer, 1996; Koutalos and Yau, 1996; Sagoo and Lagnado, 1996). Indeed, the transduction function of rods that express CNG channels that cannot be modulated by $\mathrm{Ca}^{2+}$ in transgenic mice is essentially the same as that of normal rods (Chen et al., 2010).

In cone photoreceptors, the $\mathrm{Ca}^{2+}$-dependent modulation of CNG channels is robust, and its $\mathrm{Ca}^{2+}$ sensitivity is in the same concentration range as the light-dependent changes in free cytoplasmic $\mathrm{Ca}^{2+}$ (Sampath et al., 1999; Rebrik et al., 2000). Because CNG channel activity is controlled by both $\mathrm{Ca}^{2+}$ and cGMP, channel reopening is faster during the recovery phase of the photoresponse than would be the case if only cGMP controlled their activity (Korenbrot, 2012); that is, $\mathrm{Ca}^{2+}$-dependent modulation of channels in cones, just as in OSNs, results in quicker recovery of the transduction signal at the end of their response. In cones, CNG channel modulation by $\mathrm{Ca}^{2+}$ contributes to the control of the sensitivity, time course, and stability of the photoresponse (Korenbrot, 2012). In this study, we have molecularly identified and functionally verified the novel CNG-modulin, a unique protein that mediates this $\mathrm{Ca}^{2+}$-dependent ligand sensitivity modulation in fish cones.

CNG-modulin meets key criteria expected of the authentic modulator in cones. (1) It is expressed in the outer segments and distributed throughout the cytoplasm. (2) In its presence, the ligand sensitivity of CNG channels is $\mathrm{Ca}^{2+}$ dependent to an extent and with concentration dependence indistinguishable from that measured in intact photoreceptors (Table 2). (3) It binds specifically to the amino terminal cytoplasmic domain of the cone CNG channel $\beta$ subunit. (4) It binds $\mathrm{Ca}^{2+}$ with high specificity and over a concentration range that overlaps the $\mathrm{Ca}^{2+}$ sensitivity of channel modulation.

CNG-modulin is present both in the inner and outer segments, perhaps not surprisingly since it is a soluble protein, and there is no reason to expect it to be sequestered in the outer segment. Indeed other proteins associated with the regulation of the phototransduction process, cone arrestin, for example, are free to translocate between inner and outer segments (Zhu et al., 2002). Also, CNG ion channels function in the cone inner segment (Savchenko et al., 1997), and CNGmodulin might interact with them. The protein is not exclusively expressed in cone photoreceptors. Immunological staining pattern revealed a subset of inner retina neurons that express CNGmodulin. In fish retina, a subset of bipolar cells express $\mathrm{CNG}$ ion channels identical to those expressed in the cones (Henry et al., 2003). Several of the tissues that express CNG-modulin mRNA in striped bass are also known to express functional CNG channels in other vertebrates: hair cells in the auditory system (Kolesnikov et al., 1991), certain neurons in specific brain regions (Timpe et al., 1999), and in kidney, where cone CNG channels are specifically expressed (Karlson et al., 1995; Novaira et al., 2004).

CNG-modulin binds $\mathrm{Ca}^{2+}$ with high affinity and in the same concentration range as the $\mathrm{Ca}^{2+}$-dependent modulation of CNG channels. $\mathrm{Mg}^{2+}$ interacts with the protein with different properties than does $\mathrm{Ca}^{2+}$. Compared with $\mathrm{Ca}^{2+}, \mathrm{Mg}^{2+}$ causes a decrease, not an increase, in intrinsic protein fluorescence, and does so at higher concentrations. The effect of $\mathrm{Mg}^{2+}$ could reflect low-affinity binding or nonspecific electrostatic interaction. Regardless of the mechanism, the difference between the effects of $\mathrm{Ca}^{2+}$ and $\mathrm{Mg}^{2+}$ affirms that $\mathrm{Ca}^{2+}$ binding to CNG-modulin is selective and specific.

Modulation of CNG channels occurs in cones of both mammals and nonmammals ((Rebrik and Korenbrot, 1998, 2004). We elected to search for CNG-modulin in the striped bass retina because the protein function is quantitatively best characterized in this animal model and, therefore, it is the species in which the function of candidate modulator proteins could be compared with that of the authentic modulator with the highest stringency. In silico search of genomic sequence (BLAST at the Swiss Institute of Bioinformatics) revealed that proteins highly homologous to bass CNG-modulin exist in other fish: T. nigroviridis [identities, 218 of 302 aa $(66 \%)$; positives, 242 of 302 aa (74\%)] and D. rerio [identities, 126 of 279 (45\%); positives, 163 of 279 (58\%)]. The closest homolog in mammals is Emll (also known as EMAP-1), a 
protein of unspecified function found in numerous species. Eml1 is larger than CNG-modulin (>800 aa), but its leading $\sim 180$ aa are highly homologous to CNG-modulin [65 of 178 aa (34\%) are identical, and 83 of $178(46 \%)$ are positive matches]. Emll is known to be expressed in human and mouse retina (NEIBank data; http://neibank.nei.nih.gov) and future work will investigate its possible function as a cone channel modulator.

Comparison with consensus functional sequences (PROSITE database) suggests that with $98 \%$ identity, CNG-modulin has sites for $\mathrm{N}$-glycosylations and phosphorylation by several different types of kinases. Many other potential functional sites have $<80 \%$ identity. Consensus secondary structure analysis (Network Protein Sequence Analysis) indicates CNG-modulin is a soluble protein that lacks any membrane-associating amphipathic domain. Approximately $75 \%$ of the protein is a random coil, and $20 \%$ is $\alpha$ helical. Two regions of helical order exist, one between amino acids 9 and 19, and the other between amino acids 63 and 109. The remaining 5\% is an extended strand.

CNG and cyclic nucleotide-regulated channels constitute a large collection of channels functionally expressed throughout the nervous system, as well as in other systems. The recognition in a few cells so far that gating of these channels depends not only on cyclic nucleotides but also on $\mathrm{Ca}^{2+}$ suggests that such dual channel control is a refined physiological tool that may be found in other cells responsive to intracellular second messengers. CNGmodulin is the first example of what may be a class of previously unrecognized $\mathrm{Ca}^{2+}$ binding molecules that serve to bring $\mathrm{Ca}^{2+}$ dependent control to other ion channels, and perhaps, more generically, to proteins that are regulated by cytoplasmic $\mathrm{Ca}^{2+}$.

\section{References}

Barthel LK, Raymond PA (1990) Improved method for obtaining 3-microns cryosections for immunocytochemistry. J Histochem Cytochem 38:1383-1388.

Bauer PJ (1996) Cyclic GMP-gated channels of bovine rod photoreceptors: affinity, density and stoichiometry of $\mathrm{Ca}^{2+}$-calmodulin binding sites. J Physiol 494:675-685.

Biel M, Michalakis S (2009) Cyclic nucleotide-gated channels. Handb Exp Pharmacol 111-136.

Bradley J, Reisert J, Frings S (2005) Regulation of cyclic nucleotide-gated channels. Curr Opin Neurobiol 15:343-349.

Bryant DT (1985) Quin 2: the dissociation constants of its $\mathrm{Ca}^{2+}$ and $\mathrm{Mg}^{2+}$ complexes and its use in a fluorimetric method for determining the dissociation of $\mathrm{Ca}^{2+}$-protein complexes. Biochem J 226:613-616.

Centonze VE, Sun M, Masuda A, Gerritsen H, Herman B (2003) Fluorescence resonance energy transfer imaging microscopy. Methods Enzymol 360:542-560.

Chen J, Woodruff ML, Wang T, Concepcion FA, Tranchina D, Fain GL (2010) Channel modulation and the mechanism of light adaptation in mouse rods. J Neurosci 30:16232-16240.

Chen TY, Yau KW (1994) Direct modulation by $\mathrm{Ca}^{2+}$-calmodulin of cyclic nucleotide-activated channel of rat olfactory receptor neurons. Nature 368:545-548.

Frings S, Lynch JW, Lindemann B (1992) Properties of cyclic nucleotidegated channels mediating olfactory transduction. Activation, selectivity, and blockage. J Gen Physiol 100:45-67.

Gordon SE, Downing-Park J, Zimmerman AL (1995) Modulation of the cGMP-gated ion channel in frog rods by calmodulin and an endogenous inhibitory factor. J Physiol 486:533-546.

Grunwald ME, Yu WP, Yu HH, Yau KW (1998) Identification of a domain on the beta-subunit of the rod cGMP-gated cation channel that mediates inhibition by calcium-calmodulin. J Biol Chem 273:9148-9157.

Hackos DH, Korenbrot JI (1997) Calcium modulation of ligand affinity in the cyclic GMP-gated ion channels of cone photoreceptors. J Gen Physiol 110:515-528.

Hackos DH, Korenbrot JI (1999) Divalent cation selectivity is a function of gating in native and recombinant cyclic nucleotide-gated ion channels from retinal photoreceptors. J Gen Physiol 113:799-818.
Haynes LW, Stotz SC (1997) Modulation of rod, but not cone, cGMP-gated photoreceptor channels by calcium-calmodulin. Vis Neurosci 14:233239.

Henry D, Burke S, Shishido E, Matthews G (2003) Retinal bipolar neurons express the cyclic nucleotide-gated channel of cone photoreceptors. J Neurophysiol 89:754-761.

Hsu YT, Molday RS (1993) Modulation of the cGMP-gated channel of rod photoreceptor cells by calmodulin. Nature 361:76-79.

Jones EB, Nelson DJ, Turnbull MM (1992) Enhancement and quenching of fluorescence of Quin-2 by metal ions. J Inorg Biochem 45:85-92.

Karlson KH, Ciampolillo-Bates F, McCoy DE, Kizer NL, Stanton BA (1995) Cloning of a cGMP-gated cation channel from mouse kidney inner medullary collecting duct. Biochim Biophys Acta 1236:197-200.

Kaupp UB, Seifert R (2002) Cyclic nucleotide-gated ion channels. Physiol Rev 82:769-824.

Kolesnikov SS, Rebrik TI, Zhainazarov AB, Tavartkiladze GA, Kalamkarov GR (1991) A cyclic-AMP-gated conductance in cochlear hair cells. FEBS Lett 290:167-170

Korenbrot JI (2012) Speed, adaptation and stability of the response to light in cone photoreceptors: the functional role of $\mathrm{Ca}$-dependent modulation of ligand-sensitivity in cGMP-gated ion channels. J Gen Physiol 139: 31-56.

Koutalos Y, Yau KW (1996) Regulation of sensitivity in vertebrate rod photoreceptors by calcium. Trends Neurosci 19:73-81.

Kramer RH, Siegelbaum SA (1992) Intracellular $\mathrm{Ca}^{2+}$ regulates the sensitivity of cyclic nucleotide-gated channels in olfactory receptor neurons. Neuron 9:897-906.

Kurahashi T, Menini A (1997) Mechanism of odorant adaptation in the olfactory receptor cell. Nature 385:725-729.

Kurahashi T, Shibuya T (1990) $\mathrm{Ca}^{2+}$-dependent adaptive properties in the solitary olfactory receptor cell of the newt. Brain Res 515:261-268.

Lakowicz JR (1999) Principles of fluorescence spectroscopy. New York: Kluwer Academic/Plenum.

Leinders-Zufall T, Ma M, Zufall F (1999) Impaired odor adaptation in olfactory receptor neurons after inhibition of $\mathrm{Ca}^{2+} /$ calmodulin kinase II. J Neurosci 19:RC19.

Lin YP, Raman R, Sharma Y, Chang YF (2008) Calcium binds to leptospiral immunoglobulin-like protein, $\mathrm{LigB}$, and modulates fibronectin binding. J Biol Chem 283:25140-25149.

Liu M, Chen TY, Ahamed B, Li J, Yau KW (1994) Calcium-calmodulin modulation of the olfactory cyclic nucleotide-gated cation channel. Science 266:1348-1354.

Lynch JW, Lindemann B (1994) Cyclic nucleotide-gated channels of rat olfactory receptor cells: divalent cations control the sensitivity to cAMP. J Gen Physiol 103:87-106.

Muranyi A, Finn BE (eds.) (2006) Calcium and its Enzymes. Boca Raton, FL: CRC.

Nakatani K, Koutalos Y, Yau KW (1995) $\mathrm{Ca}^{2+}$ modulation of the cGMPgated channel of bullfrog retinal rod photoreceptors. J Physiol 484:69-76.

Novaira HJ, Botelho BF, Goldenberg RC, Guggino SE, Morales MM (2004) Modulation of renal CNG-A3 sodium channel in rats subjected to lowand high-sodium diets. Biochim Biophys Acta 1665:101-110.

Paillart C, Zhang K, Rebrik TI, Baehr W, Korenbrot JI (2006) Cloning and molecular characterization of cGMP-gated ion channels from rod and cone photoreceptors of striped bass (M. saxatilis) retina. Vis Neurosci 23:99-113

Panavas T, Sanders C, Butt TR (2009) SUMO fusion technology for enhanced protein production in prokaryotic and eukaryotic expression systems. Methods Mol Biol 497:303-317.

Peng C, Rich ED, Thor CA, Varnum MD (2003) Functionally important calmodulin-binding sites in both $\mathrm{NH} 2$ - and $\mathrm{COOH}$-terminal regions of the cone photoreceptor cyclic nucleotide-gated channel CNGB3 subunit. J Biol Chem 278:24617-24623.

Periasamy A, Day R (2005) Molecular imaging: FRET microscopy and spectroscopy. Oxford, UK: Oxford University Press.

Picones A, Korenbrot JI (1992) Permeation and interaction of monovalent cations with the cGMP-gated channel of cone photoreceptors. J Gen Physiol 100:647-673.

Rebrik TI, Korenbrot JI (1998) In intact cone photoreceptors, a $\mathrm{Ca}^{2+}$ dependent, diffusible factor modulates the cGMP-gated ion channels differently than in rods. J Gen Physiol 112:537-548.

Rebrik TI, Korenbrot JI (2004) In intact mammalian photoreceptors, $\mathrm{Ca}^{2+}$. 
dependent modulation of cGMP-gated ion channels is detectable in cones but not in rods. J Gen Physiol 123:63-76.

Rebrik TI, Kotelnikova EA, Korenbrot JI (2000) Time course and $\mathrm{Ca}^{2+} \mathrm{de}-$ pendence of sensitivity modulation in cyclic GMP-gated currents of intact cone photoreceptors. J Gen Physiol 116:521-534.

Reuter D, Frings S (2001) Facilitation of calmodulin-mediated odor adaptation by cAMP-gated channel. Science 294:2176-2178.

Rhodes KJ, Trimmer JS (2006) Antibodies as valuable neuroscience research tools versus reagents of mass distraction. J Neurosci 26:8017-8020.

Sagoo MS, Lagnado L (1996) The action of cytoplasmic calcium on the cGMP-activated channel in salamander rod photoreceptors. J Physiol 497:309-319.

Sampath AP, Matthews HR, Cornwall MC, Bandarchi J, Fain GL (1999) Light-dependent changes in outer segment free- $\mathrm{Ca}^{2+}$ concentration in salamander cone photoreceptors. J Gen Physiol 113:267-277.

Savchenko A, Barnes S, Kramer RH (1997) Cyclic-nucleotide-gated channels mediate synaptic feedback by nitric oxide. Nature 390:694-698.

Song Y, Cygnar KD, Sagdullaev B, Valley M, Hirsh S, Stephan A, Reisert J, Zhao H (2008) Olfactory CNG channel desensitization by $\mathrm{Ca}^{2+} / \mathrm{CaM}$ via the B1b subunit affects response termination but not sensitivity to recurring stimulation. Neuron 58:374-386.
Tatsumi R, Shimada K, Hattori A (1997) Fluorescence detection of calciumbinding proteins with quinoline Ca-indicator quin2. Anal Biochem 254:126-131.

Teale FW, Weber G (1957) Ultraviolet fluorescence of the aromatic amino acids. Biochem J 65:476-482.

Timpe LC, Jin KL, Puelles L, Rubenstein JL (1999) Cyclic nucleotide-gated cation channel expression in embryonic chick brain. Brain Res Mol Brain Res 66:175-178.

Trudeau MC, Zagotta WN (2003) Calcium/calmodulin modulation of olfactory and rod cyclic nucleotide-gated ion channels. J Biol Chem 278:18705-18708.

Varnum MD, Zagotta WN (1997) Interdomain interactions underlying activation of cyclic nucleotide-gated channels. Science 278:110-113.

Weitz D, Zoche M, Muller F, Beyermann M, Korschen HG, Kaupp UB, Koch KW (1998) Calmodulin controls the rod photoreceptor CNG channel through an unconventional binding site in the $\mathrm{N}$-terminus of the betasubunit. EMBO J 17:2273-2284.

Zhu X, Li A, Brown B, Weiss ER, Osawa S, Craft CM (2002) Mouse cone arrestin expression pattern: light induced translocation in cone photoreceptors. Mol Vis 8:462-471. 